\title{
Cultural attitudes are stronger predictors of bushmeat consumption and preference than economic factors among urban Amazonians from Brazil and Colombia
}

\author{
Carla Morsello $^{1,2}$, Blanca Yagüe ${ }^{3}$, Letícia Beltreschi ${ }^{1}$, Nathalie van Vliet ${ }^{4}$, Cristina Adams ${ }^{1,2}$, Tatiana Schor ${ }^{5}$, Maria Paula Quiceno-
} Mesa $^{6}$ and Daniel Cruz $^{6}$

\begin{abstract}
Bushmeat consumption persists in urban areas in the Neotropics, yet knowledge of its scale and the relative importance of cultural and economic factors in determining consumption and preference remain elusive. Moreover, the roles of cultural beliefs, social norms, and attitudes in driving urban bushmeat consumption are rarely evaluated. Therefore, we explored in this article the factors that influence consumption and preference for bushmeat in Amazonian towns. Given the availability of other sources of animal protein and the cultural and social importance of bushmeat in the region, we hypothesized that cultural attributes should be better predictors than economic factors of bushmeat consumption and preference. Data analysis involved fitting two-level mixed-effects regressions (random intercepts) to a structured sample of 227 individuals ( 99 households) from four towns in the Brazilian (Tabatinga and Atalaia do Norte) and Colombian (Leticia and Puerto Nariño) Amazon. The results indicate that a third of the interviewees had consumed bushmeat in the past month, which had primarily been harvested by the family or received as a gift rather than obtained through trade. In general, both economic and cultural factors predicted bushmeat consumption and preference, but the objective proxy for culture, individual origin, was unimportant. Among the tested indicators, the strongest predictor was the importance of bushmeat to social relations. Moreover, informal social norms, such as the greater importance attributed to taboos, tended to decrease the average number of wild species that a person would eat, whereas attitudes toward the illegality of hunting were less important. The two economic indicators, increased income and wealth, tended to decrease preference for bushmeat and the likelihood of consumption. Our findings highlight the importance of human beliefs, attitudes, and social norms to the understanding of bushmeat consumption and preference and may contribute to the design of more effective and locally appropriate conservation and management strategies.
\end{abstract}

Key Words: attitudes; beliefs; bushmeat sharing; human behavior; hunting; income; legality; social norms; social relations; taboos; wealth

\section{INTRODUCTION}

Bushmeat, i.e., meat that predominantly comes from wild vertebrates, represents the primary source of protein in forested areas of the tropics (Fa et al. 2002a, Milner-Gulland and Bennett 2003). The rationale for bushmeat consumption in remote rural areas is self-evident: the resource can be directly accessed, and domesticated proteins are expensive or unavailable (Willcox and Nambu 2007). However, why does bushmeat consumption persist in urban areas? Although the answer to this question is less straightforward, understanding the drivers of urban bushmeat consumption is important because the demand from larger human populations represents a substantial threat to wild animals in natural areas (Wilkie and Carpenter 1999). Consequently, in addition to affecting the sustainability of wild game populations, urban bushmeat consumption can threaten the food security of rural people, who most depend on wild game, by reducing the availability of the resource (Milner-Gulland and Bennett 2003, Nasi et al. 2011).

The current literature on the drivers of bushmeat consumption has predominantly approached this question within the framework of rational choice theory, which assumes that individuals have a more-or-less perfect perception of the world through which they make decisions in a social vacuum (Lunt 2006, Tucker 2007). In the most basic formulation of this decision model, an individual with a given set of desires will seek to maximize utility by tallying benefits and costs (MacFayden 2006). Therefore, when constrained by wealth and the availability of animal proteins, individuals will make consumptive choices that maximize their intake of their preferred species.

Within this implicit framework, studies have evaluated the association between economic drivers, i.e., income or wealth, and bushmeat consumption, and the accumulated evidence from urban areas, mostly in west and central Africa, appears contradictory. Although at least one study found that higher household income is associated with reduced bushmeat consumption in West Africa (Albrechtsen et al. 2005), additional findings have shown that increases in income (Mbete et al. 2011), wealth (as measured through expenditures; Fa et al. 2009), or both (East et al. 2005, Brashares et al. 2011, Jenkins et al. 2011) may increase bushmeat consumption.

The reason for these conflicting results is that consumptive behavior not only depends on people's preferences but also on income and prices. If the price of a certain good is held constant, an increase in income will typically lead to higher levels of consumption, so when an increase in income produces an increase in bushmeat consumption, bushmeat is considered a normal good (Mankiw 2009). For products that are highly preferred for cultural reasons or taste, levels of consumption would rise even higher with a proportional increase in income; in this case, bushmeat would be considered a superior good (Wilkie and Godoy 2001). Under this scenario, the wealthy would tend to consume more bushmeat than the poor, and consumption might persist even with higher prices (Wilkie and Carpenter 1999). However, if people

\footnotetext{
${ }^{1}$ Escola de Artes, Ciências e Humanidades, Universidade de São Paulo, Brazil, ${ }^{2}$ Instituto de Energia e Ambiente, Universidade de São Paulo, Brazil, ${ }^{3}$ Independent consultant, ${ }^{4}$ Center for International Forestry Research, ${ }_{5}^{5}$ Departamento de Geografia, Universidade Federal do Amazonas, Brazil, ${ }^{6}$ Fundación Science International, Colombia
} 
were to have a low preference for bushmeat compared to other protein sources, an increase in income might be accompanied by a lower proportional increase in consumption, and bushmeat would be considered an inferior good. However, under this last scenario, people with low incomes would rely on bushmeat more than do wealthy people if it were easily available and less expensive than other animal proteins (van Vliet et al. 2012).

Previous research has shown that economic factors and preferences influence the levels of bushmeat consumption. However, general studies of food consumption indicate that foodrelated behavior is modified by culture, and a substantial percentage of the variance in the amounts and types of items being consumed cannot be explained by availability or differences in socioeconomic status (Axelson 1986). Even when people prefer a certain food, they may not choose to consume it at high levels for reasons related to economic, perceived nutrition, convenience, and cultural and attitudinal aspects (Drewnowski 1997).

Cultural aspects, mediated through taste (Schenck et al. 2006), have indeed been widely reported to be important in explaining bushmeat consumption (e.g., van Vliet and Mbazza 2011). Typically, people whose rural traditions do not include bushmeat consumption are less likely to eat it when they move to urban environments (Naughton-Treves 2002) because individuals often express negative feelings toward unfamiliar foods (Schenck et al. 2006). To test this hypothesis, studies have assessed the effects of origin, as a proxy for culture, on bushmeat consumption and preferences and have shown that they differ across ethnicities (Fa et al. 2002b, East et al. 2005, Mbete et al. 2011) and with indicators of origin, such as being autochthonous or a recent immigrant (Gavin and Anderson 2007, Poulsen et al. 2009) or coming from an urban or rural setting (Schenck et al. 2006).

However, origin is a poor proxy for the complex cognitive factors that drive behavior and may vary among individuals who share a given origin. Furthermore, because origin is a constant, knowledge of its effects is important for science but less so for policy. Theoretical models based on social psychology (Ajzen 1991) and behavioral economics that incorporate psychosocial attributes (Altman 2006) indicate that aspects of cognition beyond rationality, such as values, beliefs, attitudes, and social norms, explain consumptive behaviors and choices. Attitudes, i.e., positive or negative individually based evaluations of an object or situation (Manfredo 2008), have been reported to be key predictors of behaviors associated with bushmeat and hunting. For example, there is evidence that attitudes concerning the role of sharing bushmeat in the fulfilment of social, cultural, and political needs are equally important in rural and urban areas (Wiessner 2002, Kaltenborn et al. 2005, Patton 2005). Beliefs about the sustainability of bushmeat consumption also shape behavior (Lee et al. 2009), which is why the topic is frequently the subject of conservation campaigns (Milner-Gulland and Bennett 2003). Additionally, compliance with social norms, or group-held perceptions of socially acceptable behaviors (Manfredo 2008), may also determine choices and behavior. For example, attitudes regarding informal institutions, such as taboos (Jones et al. 2008, Luzar et al. 2012), and formal laws, such as the illegality of hunting, may influence bushmeat consumption.

Therefore, beliefs, attitudes, and social norms are good predictors of behavior, but they can also be changed; these two critical points have made the topic very popular in investigations into the human dimensions of natural resource conservation (Manfredo et al. 2004). In contrast, the culturally determined, psychosocial aspects of behavior are seldom addressed in predictive models of bushmeat consumption and preferences in the tropics (but see Lee et al. 2009). Current studies mainly focus on origin as the sole cultural predictor, while other attributes are seldom operationalized into variables that can be used in hypothesis testing, which is a more pronounced problem in urban studies. This neglect is problematic because bushmeat consumption has consistently been portrayed as having great symbolic value in both industrial and small-scale societies (Tadie and Fischer 2013) and as being essential for gaining prestige and consolidating social networks in several cultures (Bennett and Robinson 2000, Patton 2005). We should therefore expect that rational economic choices as well as origin are insufficient or even secondary to culturally driven, psychosocial factors in explaining bushmeat consumption and preferences. Neglecting these aspects not only decreases our potential for predicting behaviors and choices but also hinders our ability to influence behavior through information provision strategies (Manfredo 2008, Heberlein 2012). For instance, this would be the case with cognitive fixes that try to change people's actions by providing them with information about the sustainability of bushmeat hunting (Manfredo 2008, Heberlein 2012).

In summary, prior research into the drivers of urban bushmeat consumption and preference has produced suggestive but inconclusive evidence for the predominance of either economic or cultural drivers (but see Gavin and Anderson 2007, Poulsen et al. 2009, Luz 2012). Moreover, the existing body of evidence is insufficient to answer the question of whether beliefs, attitudes, and social norms are important in shaping consumption and preference in urban locations. Therefore, we analyzed the drivers of urban consumption and preference for bushmeat in the Amazon and examined the relative importance of the cultural and economic aspects. Our hypothesis was that cultural attributes are better predictors than economic factors of consumption and preference because the cultural and social importance of bushmeat is likely to persist in urban areas. To test this hypothesis, we analyzed the drivers of urban bushmeat consumption and preference in Amazonian frontier towns using random-effects models applied to a survey of 227 individuals ( 99 households) selected from a structured sample from four towns of the Brazilian (Tabatinga and Atalaia do Norte) and Colombian (Leticia and Puerto Nariño) Amazon. The studied region provides an ideal setting for assessing the economic and cultural drivers of bushmeat consumption because these urban populations are composed of a mixture of people with different cultural backgrounds.

Our primary contribution is twofold: first, we add to the scarce body of evidence of the relative contributions of cultural and economic drivers to bushmeat consumption and preference, evidence that is particularly lacking for Latin America and the Amazon (Rushton et al. 2005). Previous studies in the Amazon have mainly focused on remote, rural settings (e.g., Peres and Nascimento 2006, Parry et al. 2009, Suárez et al. 2009), neglecting the consumption of urban and periurban locations (but see BaíaJúnior et al. 2010, Parry et al. 2014). Second, no assessment of a diverse set of beliefs, attitudes and social norms as drivers of 
Table 1. Characteristics of the studied areas.

\begin{tabular}{|c|c|c|c|c|}
\hline \multirow{2}{*}{$\frac{\text { Characteristic }}{\text { Towns studied }}$} & \multicolumn{2}{|c|}{ Colombia } & \multicolumn{2}{|c|}{ Brazil } \\
\hline & Leticia & Puerto Nariño & Tabatinga & Atalaia do Norte \\
\hline Official language & & Spanish & & Portuguese \\
\hline Population &, 342 & 7338 (98\% indigenous) & 52,272 & 17,174 \\
\hline Percentage of urban population & $3.0 \%$ & $27.0 \%$ & $73.4 \%$ & $45.5 \%$ \\
\hline Location: all in the Amazon river & Left bank & Left bank & $\begin{array}{l}\text { Left bank (Upper } \\
\text { Solimões) }\end{array}$ & Righ bank (Javari) \\
\hline Municipality territory & $6.243 \mathrm{~km}^{2}$ & $1.503 \mathrm{~km}^{2}$ & $3.224 \mathrm{~km}^{2}$ & $76.351 \mathrm{~km}^{2}$ \\
\hline $\begin{array}{l}\text { Presence of indigenous territories } \\
\text { in the municipality area }\end{array}$ & $\begin{array}{l}\text { Indigenous territories in } \\
\text { the periurban area }\end{array}$ & $\begin{array}{l}\text { Indigenous territories in the } \\
\text { periurban and rural area } \\
\text { ( } 92 \% \text { of the municipality) }\end{array}$ & $\begin{array}{l}\text { Indigenous territories in } \\
\text { the periurban and rural } \\
\text { areas }\end{array}$ & $\begin{array}{l}\text { Indigenous territories in } \\
\text { the rural area }\end{array}$ \\
\hline $\begin{array}{l}\text { Number of indigenous } \\
\text { ethnicieties }\end{array}$ & \multicolumn{2}{|c|}{$\begin{array}{l}\text { At least } 16 \text { in the surrounding forests and } 10 \text { ethnic } \\
\text { groups in this study (plus combinations) }\end{array}$} & \multicolumn{2}{|c|}{$\begin{array}{l}\text { At least } 7 \text { in the surrounding forests and } 3 \text { in this study } \\
\text { (plus combinations) }\end{array}$} \\
\hline Migrants & \multicolumn{4}{|c|}{ All towns: from surrounding rural and indigenous territories, and from other regions and countries (mainly Peru) } \\
\hline Interviewed population & mostly urban & urban/ periurban & mostly urban & mostly urban \\
\hline Legal income sources & $\begin{array}{l}\text { government services; } \\
\text { commerce (free } \\
\text { commerce zone); } \\
\text { commercial fishing; } \\
\text { tourism; }\end{array}$ & $\begin{array}{l}\text { small-scale subsistence } \\
\text { agriculture; } \\
\text { fishing; } \\
\text { logging; } \\
\text { commerce; } \\
\text { tourism; }\end{array}$ & $\begin{array}{l}\text { commerce (free commerce } \\
\text { zone); } \\
\text { agriculture (mainly banana } \\
\text { and manioc); } \\
\text { fishing; } \\
\text { tourism; }\end{array}$ & $\begin{array}{l}\text { services and commerce } \\
(76.4 \%) ; \\
\text { agriculture (mainly manioc, } \\
\text { sugar cane, and banana) } \\
\text { and forestry }(11.9 \%) ;\end{array}$ \\
\hline $\begin{array}{l}\text { Source of wild meat: surrounding } \\
\text { territories of both countries }\end{array}$ & \multicolumn{2}{|c|}{$\begin{array}{l}\text { Several indigenous and public or private forest reserves, } \\
\text { and a National Park (Amacayacu National Park) }\end{array}$} & \multicolumn{2}{|c|}{$\begin{array}{l}\text { Several indigenous territories (Javari is the largest) in } \\
\text { approximately } 122,000 \mathrm{~km}^{2} \text { of well-preserved seasonally } \\
\text { flooded and "terra firme" forests }\end{array}$} \\
\hline Sources of domestic meat & \multicolumn{2}{|c|}{$\begin{array}{l}\text { Local production: chicken and chicken eggs in } \\
\text { household production and small farms, small } \\
\text { production of cattle milk and pork } \\
\text { Imported: frozen chicken (southern Brazil), beef } \\
\text { (Putumayo region) }\end{array}$} & \multicolumn{2}{|c|}{$\begin{array}{l}\text { Local production: chicken and chicken eggs in } \\
\text { household production, small production of cattle milk } \\
\text { and pork } \\
\text { Imported: frozen chicken (southern Brazil) and beef } \\
\text { (Santarém) }\end{array}$} \\
\hline
\end{tabular}

bushmeat consumption and preference in urban areas is known to us despite the importance of such knowledge to the development and implementation of successful, locally legitimate conservation strategies (Lee et al. 2009, Bitanyi et al. 2012, Walters et al. 2014).

\section{METHODS}

\section{Study area}

The data used in this study come from a household survey conducted in four municipalities, two in Brazil (Tabatinga and Atalaia do Norte) and two in Colombia (Leticia and Puerto Nariño; Fig. 1), located on the frontier between the two countries in the western Amazon. All of the towns are located on the banks of the Amazon River and share some environmental and socioeconomic characteristics but vary in their official languages, predominant land uses, territory sizes, ethnicities, urban infrastructure, policies, and legislation (Government of Colombia 2008, Higuchi et al. 2011, IBGE 2013, Yagüe 2013, Government of Brazil 2014). The sizes of the populations range from 7338 to 52,272 with at least half of the people inhabiting urban and periurban locations, except in Puerto Nariño, which is mostly rural (Table1).

In both countries, the study locations are surrounded by large tracts of well-preserved tropical forests (seasonally flooded, "terra firme" forests) in public or private protected areas and indigenous territories (Valle 2006, Ricardo and Ricardo 2011, Yagüe 2013). Bushmeat is legally hunted by residents or illegally by nonresidents and then consumed at home or illegally traded.
Although fish is locally harvested and traded, local production of domestic animal protein is restricted to chicken and chicken eggs, with a much smaller contribution from cow's milk and pork (Higuchi et al. 2011). Other animal proteins are imported, including frozen chicken from southern Brazil, which is sold in both countries, and beef from Santarém in the Brazilian Amazon (Nardoto et al. 2011) and the Putumayo Department of Colombia (Yagüe 2013). The two largest towns, Tabatinga and Leticia, form a contiguous urban settlement where people might travel to another country simply by crossing a street. Thus, residents are able to purchase food with both currencies and can easily move purchased and extracted goods, such as bushmeat, across borders. Furthermore, both Leticia and Tabatinga are free-commerce zones, where products destined for local consumption are free of import fees (except for guns in both countries as well as ammunition, alcoholic beverages, cars, cigarettes, and perfumes in Brazil and precursor substances for producing drugs in Colombia; Government of Brazil 2014).

With the exception of Puerto Nariño, which depends on subsistence agriculture (Yagüe 2013), the main source of income in the studied towns is the tertiary sector (services and commerce) followed by agriculture in Brazil and tourism and commercial fishing in Colombia (Government of Colombia 2008, Girón 2010, Yagüe 2013, Government of Brazil 2014). Because Leticia is the department capital and thus provides many government services, there is significant reliance on government employment that attracts migrants from other regions. In Tabatinga, some employment is provided by a military base, which also attracts temporary or permanent migrants. Government transferences, such as 
Fig. 1. Map of the study area indicating the towns surveyed.

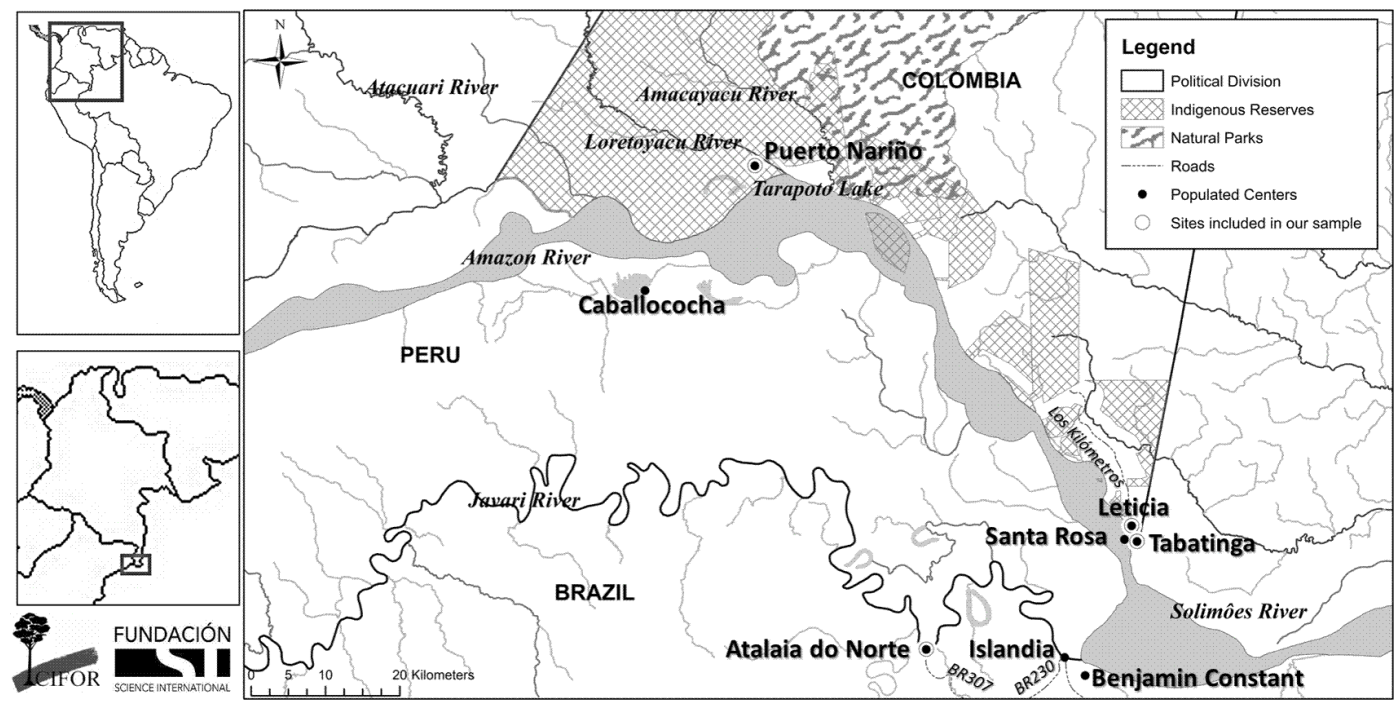

conditional cash payments, pensions, and temporary transferences, e.g., maternity leave, are also important sources of income, particularly in Brazil. Industry is practically nonexistent in all of the locations as is common in the Amazon. Despite the difficulties in estimating their contributions, drug trafficking and, to a much lesser degree, illegal logging likely also contribute to the local economic dynamics of the studied towns (Magalhães 2000, Zarate 2008)

The studied towns are multicultural and include a variety of ethnic groups and modern and traditional cultures with diverse origins and customs (Hurtado 2005). Several indigenous ethnicities are represented in the studied towns, and portions of the municipalities lie within recognized indigenous territories (Table 1; Nascimento 2001, Yagüe 2013, Government of Colombia 2015). Migrants from other regions of the respective countries and from other countries in the region, mainly Peru, also converge on the area. Urban and periurban households often maintain links with kindred in rural areas (Yagüe 2014), which occasionally include multisited households with houses and members in multiple locations (Padoch et al. 2008).

This local socioeconomic and cultural diversity provides an ideal setting in which to evaluate the influence of economic and cultural correlates of bushmeat consumption and preference. The overall context is typical of the majority of Amazonian towns in terms of population size (less than 50,000 inhabitants; IBGE 2013) and the degree of immersion in forested landscapes (Parry et al. 2014), as well as accessibility in regard to locations reached only by river networks (Schor et al. 2014).

\section{Data collection}

From May to July 2013, we surveyed 227 individuals (108 in Brazil and 119 in Colombia) from 99 households (51 in Brazil and 48 in Colombia) with multiple-choice questions disseminated through face-to-face interviews. Two survey protocols were developed: one directed toward households and another toward individuals from these same households. Under the first protocol, we collected information on household demographics, income, and wealth by interviewing either an auto-determined household head (man or woman) or an adult ( $\geq 15$ years) indicated by the family to be knowledgeable of the incomes of the other members. The second protocol addressed one to three adults in the household and gathered information about the interviewees' characteristics, bushmeat consumption, meat preferences (wild and domestic), and cultural determinants of bushmeat consumption, i.e., origin, beliefs, attitudes, and social norms. Because the common names of species differed across ethnic origins or because people could not name them, we used plates with animal figures to facilitate accurate identification during the preference evaluation. The questions underwent several rounds of pretesting in both countries and were reviewed before use.

\section{Sampling design}

Trading in wildlife is illegal in both countries, and only subsistence hunting by rural populations is allowed. For this reason, urban inhabitants may underreport bushmeat consumption when directly approached in the streets or in their houses, so a threestep sampling procedure was used to gain people's confidence in this study.

The first step consisted of supplying self-administered questionnaires, which included a survey of meat consumption (domestic and wild) over 24 hours and information about household assets to estimate wealth (see van Vliet et al. 2015a), to pupils (12 to 16 years old) from 11 schools. The survey was repeated in the wet and dry seasons; a total of 886 children in the dry season and 1046 in the wet season were questioned. With this information, we classified the sample of schoolchildren that had eaten bushmeat at least once into one of four combinations of bushmeat consumption (yes/no) and wealth (high/low), e.g., high wealth/consumed, low wealth/consumed, etc. We then selected a subsample of eight schools (four in Brazil and four in Colombia) from the previous sample, which represented a variety of conditions in terms of location, that included an equal proportion of households in each of the four classes to guarantee variability 
in potential bushmeat consumption and wealth. Following a written invitation sent through the schools, we contacted members of the pupils' families who agreed to participate in the survey. When we could not locate the address, we substituted the household by another in the same class. Finally, we selected the adults to be interviewed within each house, but because it was infeasible to randomly sample the individuals within each house, we interviewed those who were present and agreed to be interviewed during the scheduled time. When more than two adults were available, we split the sample between men and women and among different age classes.

As a result, the sample varies in terms of household location, wealth strata, and cultural background, which allows us to evaluate the association between economic and cultural correlates and bushmeat consumption and preference. However, in such a structured sampling procedure, the sample is not statistically representative of the population. At the individual level, our sample includes a variety of ages and both genders, but it is slightly skewed toward women ( $54 \%$ women), partly because there were households headed by women with no adult men but also because women were more frequently at home.

\section{Data analysis}

The hypothesis was tested by assessing which economic and cultural correlates (explanatory variables) predicted bushmeat consumption and preference (dependent variables) by fitting twolevel mixed-effects regressions (random intercept) and controlling for confounding factors. Levels corresponded to individuals nested within households, while country-based cluster effects were factored into the regressions as fixed effects (binary variable). Although our sampling design involved schools as another intermediary level, we did not include this variable as a random term because interschool variability was not found to be significant by pretesting of the three-level regressions, probably because of the number of schools sampled (8). The multilevel approach was necessary to incorporate the hierarchical nature of the sampling design, to adjust the estimate of standard-errors for the nonindependence of individuals from the same household, and to correct for the unbalanced number of level-1 units (individuals) across households (Gelman and Hill 2007). Before running the regressions, we also checked for pairwise correlations between the explanatory variables with the Sidak correction (Hamilton 2012) and excluded those that were highly correlated (pwcorr $>0.60, \mathrm{p}<0.05$ ) at the individual level.

\section{Dependent variables}

The dependent variables reflect the consumption of and preference for bushmeat at the individual level as defined by three proxies. The first, "Consumption," is the number of times a person had eaten bushmeat in the 30 days prior to the interview, which coincided with the time of year during which, according to earlier accounts, people consume bushmeat more frequently. Although this estimate is not representative of consumption over a year, we have no reason to believe that the associations between economic and cultural drivers and bushmeat consumption change during the year. Because Consumption is a count variable, we adopted a Poisson regression for its prediction (Rabe-Hesketh and Skrondal 2012). The second proxy, "Preference," is a binary variable that indicated whether bushmeat was $(=1)$ or was not $(=0)$ the most or second most-preferred type of meat, and we modeled its prediction with a logistic regression. "Acceptability," the third proxy, is the percentage of a list of 71 local wild species that a person would eat if offered. This variable estimated a person's dietary breadth, i.e., the range of bushmeat species considered suitable for consumption. The rationale for this variable assumed that people culturally accustomed to bushmeat consumption would accept a larger number of animals. In the Neotropics, a person's origin may influence the choice of the species to be consumed; for instance, when comparing indigenous people and colonists, the former tend to consume a larger number of species than the latter (see e.g., Redford and Robinson 1987).

Because people may have migrated from regions that varied in ecological conditions and game availability, we inquired about the overall number of species considered suitable for eating rather than limiting the selection to those eaten in the past because the latter estimate could be biased. We modeled Acceptability with a linear regression after checking for normality.

\section{Explanatory variables: cultural and economic correlates}

Two sets of correlates were included as explanatory variables. The first is composed of objective (origin) and subjective factors, i.e., psychosocial cultural indicators (beliefs, attitudes, and social norms), all defined at the individual level. The first proxy, "Origin," indicates the self-identified provenance of the person as indigenous $(=1)$ or nonindigenous $(=0)$.

The subjective cultural factors include four hypothetical constructs that, because they cannot be observed directly, must be inferred from measurable responses (Ajzen 2005). All four variables were estimated at the individual level and were constructed using Likert-type scales; each scale was composed of six statements, 3 positive and 3 negative (Johns 2010). A statement was a sentence that expressed a point of view, preference, or position (Oppenheim 1966) that was assessed using a 5-point ordered-response format, i.e., from "strongly agree" to "strongly disagree." Each scale, i.e., each group of six statements, had been previously checked for reliability using Cronbach's Alpha (Cronbach and Shavelson 2004) and then summed to a single factor using principal component analysis, as described by Jolliffe (2002).

The first variable, "Scarcity," refers to an individual's beliefs, and thus cognitions that can be externally validated about the probability than an object is associated with a given attribute (Albarracin et al. 2014). In particular, we investigated beliefs regarding bushmeat scarcity, i.e., whether people agreed that bushmeat is becoming difficult to obtain in the region, with higher values indicating a higher perception of scarcity. "Social relations" refer to a person's attitudes, i.e., the disposition to respond favorably or unfavorably to an object, person, institution, or event (Ajzen 2005). Specifically, it refers to a person's evaluation of whether bushmeat consumption and sharing are important aspects of their cultural identity, family life, and social networks, with higher values suggesting that a person attributes greater importance to those factors. Perceived social norms were included as two indicators of attitude that capture people's evaluations of the ways that formal and informal institutions affect their behavior. "Illegality" accounts for a person's belief that bushmeat should not or cannot be eaten because it is legally forbidden and/ or the laws are enforced, with higher values indicating stronger agreement with the statement. "Taboos" refer to informal 
Table 2. Definition and summary statistics of variables used in regressions $(n=227)$.

\begin{tabular}{|c|c|c|c|c|c|c|c|c|c|}
\hline \multirow[b]{2}{*}{ Variable } & \multirow[b]{2}{*}{ Obs. } & \multicolumn{4}{|c|}{ Unstandardized } & \multicolumn{4}{|c|}{ Standardized } \\
\hline & & Mean & Std. Dev. & Min & $\operatorname{Max}$ & Mean & Std. Dev. & Min & $\operatorname{Max}$ \\
\hline \multicolumn{10}{|l|}{ Dependent variables } \\
\hline Consumption & 227 & 0.5463 & 0.9646 & 0.0000 & 6.0000 & 0.5463 & 0.9646 & 0.0000 & 6.0000 \\
\hline Preference & 227 & 0.3172 & 0.4664 & 0.0000 & 1.0000 & 0.3172 & 0.4664 & 0.0000 & 1.0000 \\
\hline Acceptability & 227 & 0.4707 & 0.2254 & 0.0000 & 0.9394 & 0.4707 & 0.2254 & 0.0000 & 0.9394 \\
\hline \multicolumn{10}{|l|}{ Explanatory } \\
\hline Monetary income & 227 & 1379.4330 & 2306.2310 & 51.5589 & 23968.2500 & 0.1834 & 0.4716 & -1.3517 & 1.9362 \\
\hline Wealth & 227 & 9045.7590 & 7183.6350 & 136.2629 & 33772.0000 & 0.0207 & 1.1690 & -5.4810 & 2.4438 \\
\hline \multicolumn{9}{|l|}{ Cultural } & 0.9026 \\
\hline Indigenous & 227 & 0.4714 & 0.5003 & 0.0000 & 1.0000 & 0.4714 & 0.5003 & -0.4713 & 0.0529 \\
\hline Scarcity & 227 & -0.0289 & 1.0037 & -2.6391 & 1.7978 & -0.0289 & 1.0037 & -2.6391 & 1.7978 \\
\hline Social relations & 227 & -0.0304 & 1.0136 & -2.6129 & 1.0548 & -0.0152 & 0.5068 & -1.3065 & 0.5274 \\
\hline Illegality & 227 & -0.0220 & 1.0111 & -3.2626 & 1.5900 & -0.0110 & 0.5056 & -1.6313 & 0.7950 \\
\hline Taboos & 227 & -0.0231 & 1.0054 & -4.0363 & 2.0565 & -0.0115 & 0.5027 & -2.0181 & 1.0283 \\
\hline \multicolumn{10}{|l|}{ Controls } \\
\hline Man & 227 & 0.4758 & 0.5005 & 0.0000 & 1.0000 & 0.0000 & 0.5005 & -0.4757 & 0.5242 \\
\hline Age & 227 & 36.9471 & 15.1221 & 15.0000 & 82.0000 & 3.5329 & 114.8601 & -163.1665 & 345.7320 \\
\hline Rural & 227 & 0.1498 & 0.3576 & 0.0000 & 1.0000 & 0.0000 & 0.3576 & -0.1497 & 0.8502 \\
\hline Colombia & 227 & 1.4758 & 0.5005 & 1.0000 & 2.0000 & 1.4758 & 0.5005 & 1.0000 & 2.0000 \\
\hline
\end{tabular}

institutions imposed by social custom that might influence food consumption through dietary prohibition or avoidance of certain resources (e.g., freshwater dolphins, tapirs), periods of time (e.g., certain seasons), or by societal subgroups (e.g., pregnant women, ill people; Ross et al. 1978). In the Amazon, some animals are referred to as reimosos, or of being capable of causing inflammation or illness in certain people, and are thus tabooed (Pezzuti et al. 2010). Higher values indicate agreement with the opinion that taboos are important and should be followed.

Three economic indicators constituted the second set of correlates, with two of them, income and wealth, defined at the household level. "Income" refers to the monetary value earned by all family members from several sources, e.g., wages, sales, social insurance payments, in the 30 days prior to the interview converted from the local currency to international dollars, an estimate that is adjusted to purchasing power parity (see http:// data.worldbank.org). "Wealth" equals the total present value owned by the household in international dollars determined from a list of 33 physical assets, which included a range of goods that captured differences in wealth and were appropriate for urban and periurban locations, e.g., a television, car, boat, water pump. Defined at the individual level, the third economic proxy is "Price perception," a metric that captures the subjective perception of how much price influences a person's consumption of meat. Higher values in this index indicate that meat prices are more important to a person's consumption than other factors, e.g., taste. The variable was constructed following the previously described procedure for subjective cultural factors, i.e., Likerttype scales.

Explanatory variables were included in the regressions in two forms, original and standardized estimates, of which the latter enabled the direct comparison of the effect magnitude estimated at different scales (Zuur et al. 2009). Continuous variables were centralized and standardized by subtracting their mean and dividing by two times their standard deviation to set them on the same scale as the binary variables; thus, the variables have a mean of zero and standard deviations of \pm 0.5 (Gelman 2008). Additionally, four variables were used to control for confounding factors. At the individual level, these variables were male (yes = $1 ;$ no $=0$ ) and age in years, and at the household level, the variables included the country of residence $($ Brazil $=0$; Colombia $=1)$ and whether the school of origin was located in a less urbanized (rural $=1$ ) or more urbanized location (rural $=0$ ) to account for variation in the level of urbanization across localities. All statistical analyses were performed with Stata v. 13.1.

\section{RESULTS}

\section{Description of the sample}

A total of $34.5 \%$ of the sampled individuals had consumed bushmeat at least once in the previous 30 days, with a maximum of six instances (Table 2), and this pattern held across gender (men $=37.1 \%$; women $=32.3 \% ; \chi^{2}=0.615, p=0.433$ ) and country $\left(\right.$ Brazil $=33.8 \%$; Colombia $\left.=35.1 \%, \chi^{2}=0.053, p=0.818\right)$. From a list of 71 locally available species, interviewees reported having eaten an average of 23.3 species in their lifetimes $(\mathrm{SD}=13.9$ with no significant difference between countries; t-test $=-0.525, p=$ 0.458 ). In contrast, there was a small difference between the genders in the average number of species eaten: men, on average, had consumed 26.4 species $(\mathrm{SD}=13.6)$ in their lifetimes, and women reported 20.6 species on average $(\mathrm{SD}=13.7$; $\mathrm{t}$-test $=-3.348, \mathrm{p}<0.001)$. Only three people in the sample $(\sim 1 \%)$ had never tasted bushmeat, while $15 \%$ had tried 40 or more species.

Hunting by a household member (42\%) followed by gifts $(19 \%)$ were the most frequent sources of bushmeat in the last 30 days, whereas purchasing in a market (3\%) was much rarer (Fig. 2). Of the individuals in the sample, $39.6 \%$ had hunted at least once in 
their lifetimes, including $53.4 \%$ of men and $10.1 \%$ of women. In both countries, as expected, men were more likely to hunt, but in Colombia, the percentage of women who had hunted at least once in their lifetime was significantly higher $(16.7 \%)$ than in Brazil $\left(3.1 \% ; \chi^{2}=6.8, p=0.009\right)$. The opposite was true for men, who were more likely to have previously hunted in Brazil $(64.5 \%)$ than in Colombia $\left(40.7 \% ; \chi^{2}=6.55, p=0.010\right)$.

Fig. 2. Source type of bushmeat consumed by individual.

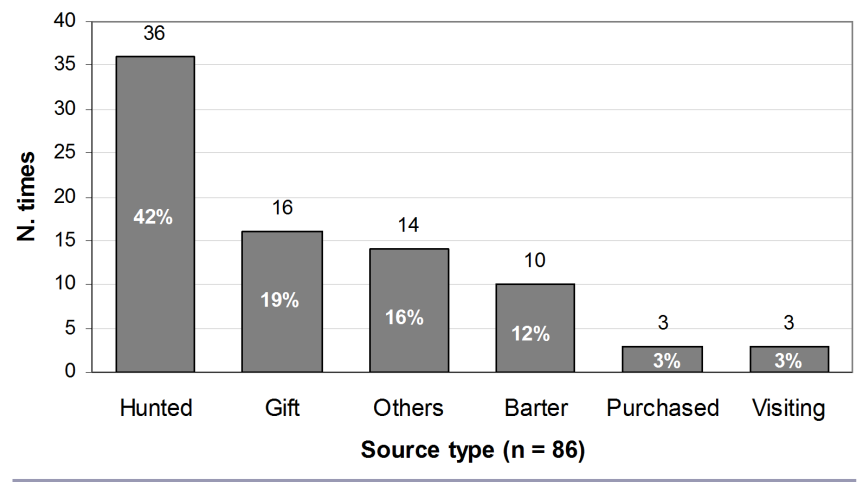

Bushmeat was chosen by $18.5 \%$ of the interviewees as their preferred type of animal protein (or $30.1 \%$ if considering their first and second choices), and it ranked fourth in the overall preference ranking after fish $(29.7 \%)$, cattle $(23.7 \%)$, and chicken (21.3\%; Fig. 3). Moreover, preference did not differ by country $\left(\chi^{2}=0.022, p=0.880\right)$ or gender $\left(\chi^{2}=1.366, p=0.243\right)$. There were differences in the preferred form of animal protein among people, but fresh proteins, accounting for almost half of people's first choice, were primarily chosen over the frozen, smoked, and salted forms (Fig. 4). Nevertheless, a substantial percentage $(21.3 \%)$ of people preferred a certain protein type regardless of its form, e.g., preferred fish whether fresh or frozen.

Fig. 3. Preference according to the type of animal protein by individual.

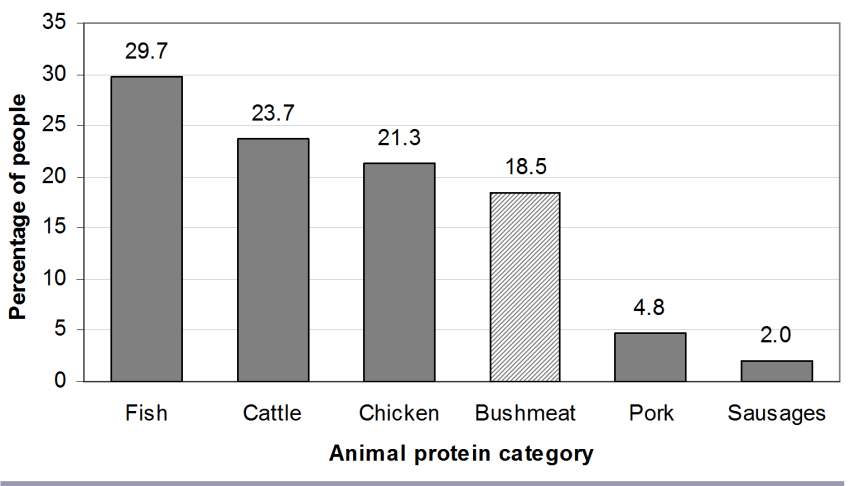

Of the species known, interviewees would, on average, accept to eat $47 \%$, but the variation was large with some who would eat none and others who would eat $93 \%$ of the offered species (SD = 0.226 ). No significant difference was observed between countries in this regard ( $\mathrm{t}$-test $=-0.380, p=0.703$ ), but women were willing to accept significantly fewer species $(40.5 \%)$ than men $(54.4 \%$; $\mathrm{t}-$ test $=-5.09, \mathrm{p}<0.001)$.
Fig. 4. Preference according to the form of animal protein by individual.

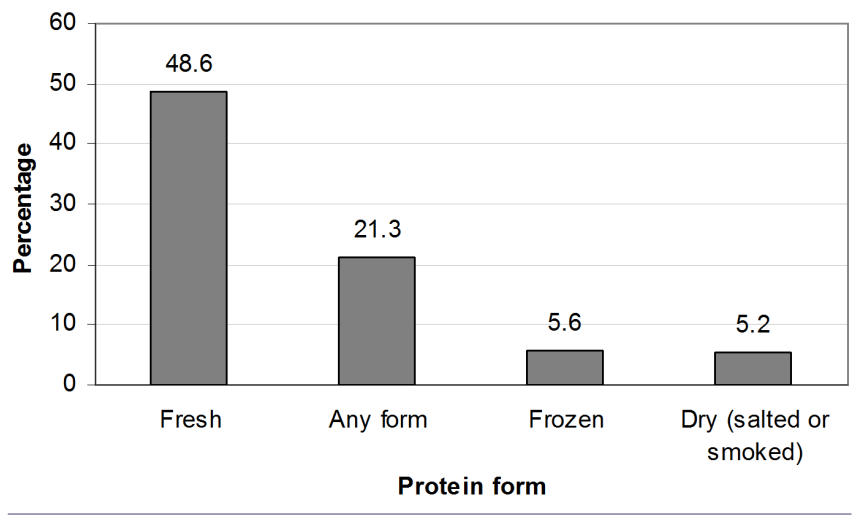

Approximately half of the interviewees (49.2\%) considered themselves to be nonindigenous; $39.9 \%$ identified as indigenous and $8.0 \%$ as partially indigenous while $2.9 \%$ did not know. However, there were substantial differences between the countries with $81.0 \%$ of Colombians reporting to be at least partially indigenous compared with $15.7 \%$ of Brazilians $\left(\chi^{2}=117.2, p<\right.$ $0.001)$. The great majority $(91.6 \%)$ were born somewhere within Amazonia, and there were no significant differences between the countries in this regard $\left(\chi^{2}=0.105, p=0.746\right)$. Most people were born in forested locations, but the percentage reported in Colombia (92.6\%) was substantially higher than in Brazil $(68.5 \%$; $\left.\chi^{2}=22.9, \mathrm{p}<0.001\right)$. As for territorial origin, $43.9 \%$ were born in indigenous territories, but the variation was large (Colombians: 80.1\%; Brazilians: 9.4\%).

Approximately $55 \%$ of the interviewees agreed that bushmeat is becoming scarce in the region, and men and women exhibited no significant differences in their responses ( $\mathrm{t}$-test $=0.774 ; p=0.439$ ). However, there were differences between the countries with Colombians reporting a higher average belief in scarceness than the Brazilians ( $\mathrm{t}$-test $=-2.022 ; p=0.044)$.

The importance attributed to Social relations in driving bushmeat consumption did not differ between countries ( $\mathrm{t}$-test $=-1.200 ; p$ $=0.232)$ or between genders $(\mathrm{t}$-test $=-0.326 ; p=0.744)$. As for social norms, the rate of agreement with the assertions that illegality decreases bushmeat consumption did not differ significantly between countries ( $\mathrm{t}$-test $=-0.424 ; p=0.671$ ), but it differed between men and women with the former attributing less importance to illegality (t-test $=1.666 ; p=0.096$ ). In contrast, attitudes toward taboos differed between countries with Brazilians reporting that taboos limited their consumption of bushmeat more frequently than the Colombians (t-test $=3.585$; $p=0.0004)$. On average, men tended to disagree with the importance of taboos whereas women tended to agree, but these differences were not significant ( $\mathrm{t}$-test $=1.084 ; p=0.279$ ).

Excluding an outlier, households earned an average of 1182 international dollars per month, but this result differed significantly by country (t-test $=2.623 ; p=0.010$ ) as well as by household within the countries. In Brazil, the average household income was I\$1421 (SD = 956.6), which was higher than in Colombia (mean = I\$965), and the average wealth was similarly 
Fig. 5. Scatterplots of significant correlates with bushmeat consumption (1a to 1c), preference (2a to 2b), and acceptability (3a to $3 \mathrm{c}$ ). Y-axis values are predicted probabilities estimated from the full models.
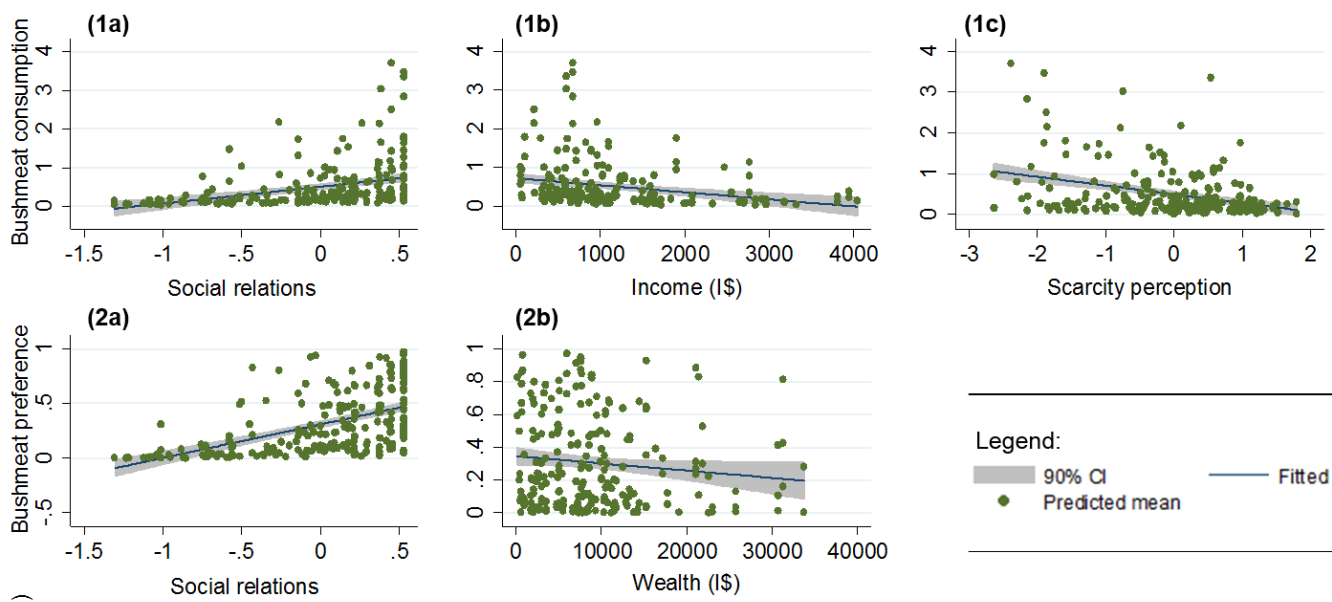

(2b)
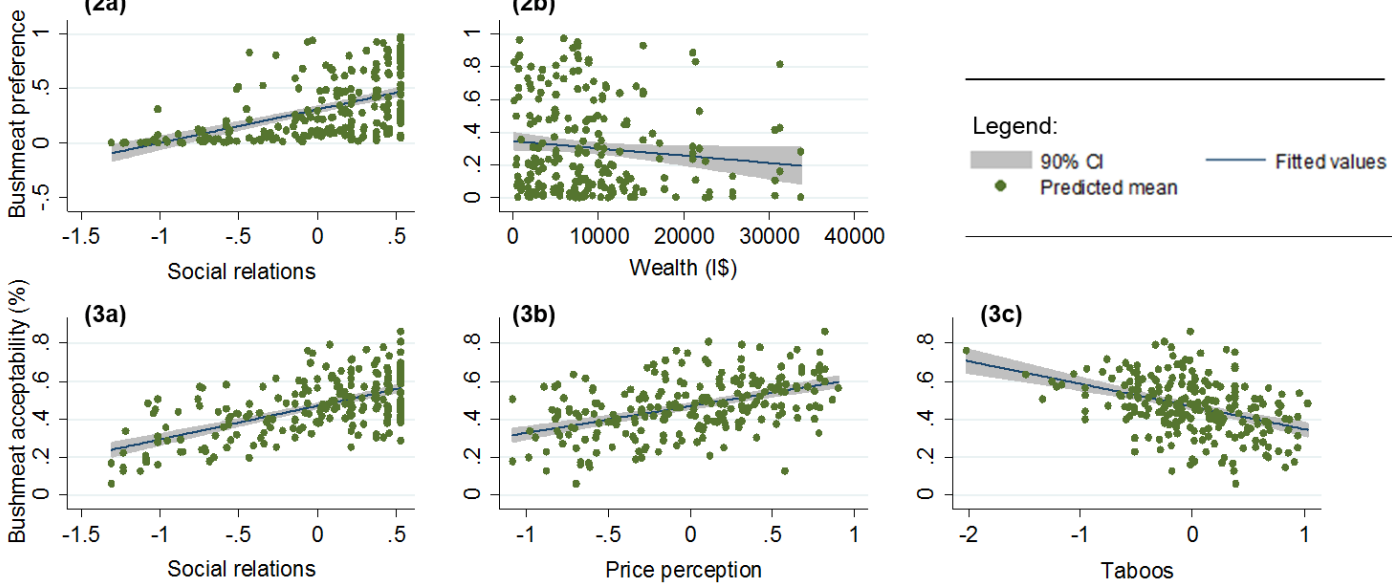

higher in Brazil than in Colombia (t-test $=3.378 ; p=0.001)$. Regarding the role of meat prices in consumptive behavior, i.e., the Price perception index, there was no difference between the countries ( $\mathrm{t}$-test $=-0.688 ; p=0.491)$ or the genders $(\mathrm{t}$-test $=0.501$; $p=0.616)$.

\section{Regression results}

In Table 3, we present the results of the association between the economic and cultural correlates and the indicators of bushmeat consumption, preference, and acceptability. The regressions in columns [1], [3], and [5] report the coefficients at their original scales, whereas columns [2], [4], and [6] display standardized coefficients. Although the original coefficients were used to interpret the magnitudes of the effect of each variable, such as the percentage increase in the rate of consumption, the standardized coefficients were adopted to compare the effect size across the variables in the regression. We evaluated the most important drivers based on the proxies for bushmeat consumption, preference, and acceptability, and compared the importance of the cultural, economic, and individual characteristics across the different models. Figure 5 displays the significant relationships between the economic and cultural correlates and the bushmeat proxies.

The frequency of consumption in the preceding 30 days was more strongly associated with the Social relations index (columns [1, 2], line [f]) after controlling for confounding variables. A one-point increase in the index, which estimated people's attitudes that the consumption and sharing of bushmeat strengthened their social networks and cultural identity, increased the rate of bushmeat consumption by $60.4 \%$. In contrast, people with higher levels of Monetary income and who believed more strongly that bushmeat is becoming scarcer in the region (Scarcity) consumed bushmeat at lower rates. However, although each additional international dollar of income decreased the rate of bushmeat consumption in the previous month by $5 \%$, a one-point increase in the index measuring attitudes toward bushmeat scarcity decreased the rate by $19.7 \%$. Furthermore, as expected, living in less urbanized and periurban locations more than doubled the rate of bushmeat consumption (line [k]).

When the outcome being considered was a strong preference for bushmeat, Social relations was also the main driver among the cultural and economic correlates (columns [3, 4], line [f]). Each additional point on the scale of the importance of Social relations attributed to bushmeat increased the odds of favoring bushmeat over other animal sources by $256 \%$. Other variables were also important in increasing the odds of preferring bushmeat, specifically being male (124\%), each additional year of age $(6 \%)$, and living in a periurban locality $(1039 \%)$. In contrast, and controlling for other factors, wealthier individuals were consistently less likely to prefer bushmeat to other sources, at least when considering the standardized variable.

In terms of bushmeat acceptability, i.e., the percentage of the bushmeat species a person would accept, the importance of Social relations was again the main predictor $($ Std. Coeff. $=0.1217)$, although gender was almost as important with men having a broader range of acceptance than women (Std. Coeff. $=0.1212$; columns [5, 6]). A one-point increase in the index of importance of bushmeat to Social relations correlated with a $6 \%$ increase in the range of bushmeat species likely to be eaten. Additionally, older people had a broader dietary acceptance than younger people, but the effect of each additional year was small (Std. 
Table 3. Results of mixed-effects regressions of the association between economic and cultural indicators with bushmeat consumption and preference.

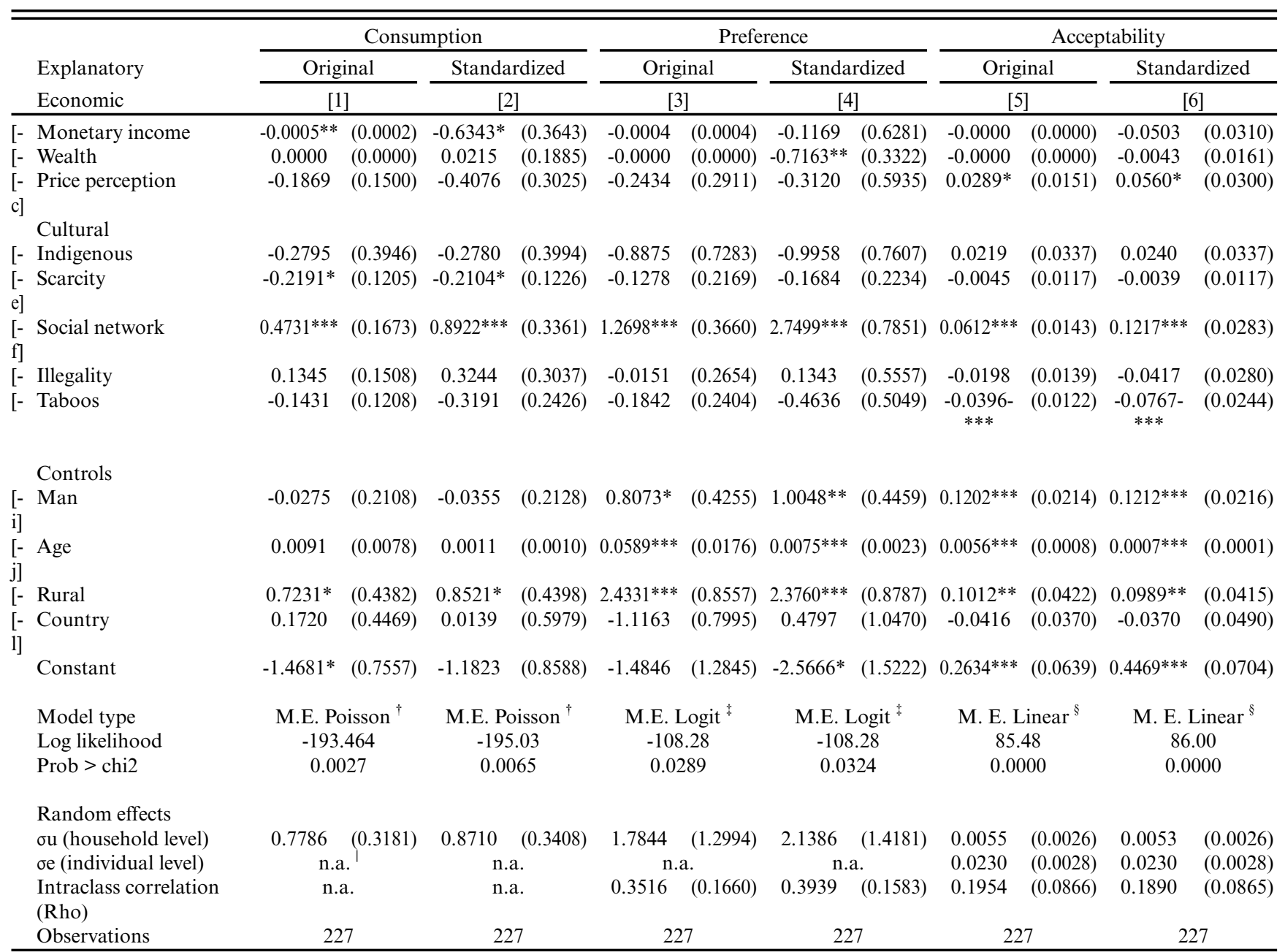

Notes: ${ }^{\dagger}$ Multilevel Mixed-Effects Poisson Regression, ${ }^{\dagger}$ Multilevel Mixed-Effects Logistic Regression (QR Decomposition), ${ }^{\S}$ Multilevel Mixed-

Effects Linear Regression, 'nonapplicable.

Standard errors in parentheses.

${ }^{*} \mathrm{p}<0.10,{ }^{* *} \mathrm{p}<0.05,{ }^{* * *} \mathrm{p}<0.01$

Coeff. $=0.0007)$. In contrast, people who attributed greater importance to taboos tended to accept a smaller percentage of wild species; each additional point in the Taboos index decreased the range of wild species likely to be eaten by a person by $7.6 \%$.

When we compare the salience of the cultural and economic indicators across the regressions, the most important predictor of eating bushmeat, preferring it over other animal proteins and eating a larger number of wild species was the importance attributed to bushmeat in the consolidation of cultural identity and the strengthening of social networks, i.e., Social relations. The Social relations coefficients were always larger and more significant (from 1.4 to 3.8 times) than coefficients of any economic indicator (columns [2, 4, 6]). Other subjective cultural aspects were also relevant but not across all of the bushmeat proxies. For instance, people attributing more importance to taboos tended to accept a significantly lower number of bushmeat species, but the effect on bushmeat consumption and preference was not significant. Similarly, people who strongly believed that bushmeat is becoming scarcer tended to consume bushmeat less frequently, but Scarcity did not correlate with other bushmeat proxies. Surprisingly, the objective cultural indicator of indigenous origin did not explain bushmeat consumption, preference or acceptability as indicated by the nonsignificant correlations with the bushmeat indicators in all of the regressions.

Though secondary to Social relations, the three economic indicators were also significant drivers of bushmeat consumption and preference, although none were significant across all of the indicators. Each additional dollar of monetary income, the shorttimespan economic indicator, lowered the rate of bushmeat consumption in the last month by $5 \%$ (column [1], line [a]) but did not explain the preference for bushmeat or the number of accepted species. Instead, the longer-term economic indicator, 
wealth in assets, decreased the odds of favoring bushmeat over other animal proteins (column [4], line [b]) but did not affect the rate of bushmeat consumption or the range of accepted wild species. The people who reported that the prices of animal proteins are very important to their consumptive decisions were less species selective, but their rate of bushmeat consumption or their preference for bushmeat over other animal sources were not affected. A one-point increase in the Price perception index increased the percentage of accepted bushmeat species by 0.12 points (column [4], line [c]).

Individual characteristics, specifically age and sex, were relevant to the preference for bushmeat and acceptability but not to consumption. Each additional year increased the odds of preferring bushmeat over other animal proteins and the range of wild species accepted but did not affect the rate of bushmeat consumption. Men were more likely to prefer bushmeat and to accept the consumption of a greater number of bushmeat species than women, but they consumed bushmeat at an equivalent rate. Controlling for other factors, living in less urbanized and periurban locations was the second most important driver of the rate of bushmeat consumption and the odds of preferring bushmeat over other animal proteins and the third most important correlate with the acceptability of wild species (columns [2,4,6], line [k]).

\section{DISCUSSION}

As previously noted by Nardoto and colleagues (2011) in a study of Amazonian towns, our results indicated that bushmeat was not the preferred source of animal protein. Nevertheless, bushmeat was routinely consumed in the towns that were studied; more than one third of the interviewees reported eating bushmeat at least once during the previous month, and $97 \%$ had consumed it in their lifetimes. These findings suggest that consuming bushmeat can be considered a local custom, although it was not an everyday food for most of the interviewees. The relative prevalence of urban bushmeat consumption in South America is in partial contrast to prior claims of its irrelevance because of the regional importance of livestock production (Rushton et al. 2005). This finding also confirms that, although bushmeat may not be the main source of animal protein in the region, its consumption is common in Amazonian towns in Brazil (Baía-Júnior et al. 2010, Parry et al. 2014) and Peru (Bodmer and Lozano 2001). For instance, in a study of a random sample of households in two other Brazilian prefrontier towns, Parry et al. (2014) found that $44 \%$ of the households had consumed bushmeat at least once during the previous month, a rate that is approximately $10 \%$ higher than our estimate. Thus, the ongoing demand for bushmeat in urban areas, even if it is sporadic, may affect wildlife populations and the rural populations in nearby territories that most depend on these resources.

There are, however, two potential sources of bias in these results. First, our study and previous research in the Amazon (e.g., Parry et al. 2014) investigated small to medium-sized towns, i.e., up to approximately 100,000 people, immersed in forested landscapes. These two characteristics may increase access to bushmeat, which could explain why urban people consume more of it. These conditions are representative of a large portion of Amazonia, although the context differs from many parts of Africa where most of the evidence comes from. In Brazil, for instance, the
Amazonian municipalities are generally small with $91.0 \%$ having up to 50,000 inhabitants (IBGE 2010 ), and the majority $(\sim 58 \%)$ existing in landscapes with at least $70 \%$ of the forest cover conserved (Parry et al. 2014). A second possible source of bias arises from our focus on towns only connected to the major urban centers through river networks, a condition that is common in western Amazonia but not in the eastern region (Schor et al. 2014). Locations connected by road networks supposedly have greater access to protein alternatives and thus lower rates of bushmeat consumption, but the evidence for this is scant. Parry et al. (2014) contradicts this hypothesis because they found higher rates of bushmeat consumption than in our survey in a town accessible through the road network. Thus, there is no empirical evidence suggesting that our results are specific to towns that can only be accessed by river, but these results must be compared across locations throughout the Amazon to provide further verification.

A second remarkable facet of the consumption patterns is that harvest and not purchase was the primary source of bushmeat in this study, contributing $42 \%$ of the monthly consumption. At first glance, the predominance of harvesting appears to contradict prior evidence from the same (van Vliet et al. 2014) and other Amazonian towns that have reported lower rates of hunting in urban households (Parry et al. 2014). Additionally, the findings contrast with evidence from Africa indicating a reliance on trade to source bushmeat for urban areas (e.g., Cowlishaw et al. 2005, Brashares et al. 2011, Lindsey et al. 2013). However, we explain why these findings are not necessarily contradictory.

Although harvesting was the main source of bushmeat in our study, this finding does not necessarily contradict prior evidence that trade is locally important (van Vliet et al. 2014). Although harvesting predominated, it represented the source of less than half of the consumption events while other categories could be directly (trade) or indirectly (gifts, others) sourced from the bushmeat trade. Additionally, tourists might consume bushmeat in local restaurants (Van Vliet et al. 2014), but we did not survey any tourists or restaurants in our study. Nevertheless, we caution that our rate of bushmeat consumption could also be an underestimate because we failed to reach some of the more wealthy households because we were unable to obtain access to a local private school. The reluctance of this segment of the population to engage in interviews leads to an underrepresentation of the wealthiest and is a well-known source of bias in household surveys (Stoop 2004). However, our conclusions still hold because even if all of the unsampled wealthy households purchased bushmeat, harvesting would still be the predominant source for local household consumption in the sample.

We are unaware of any studies that have investigated the relative contributions of hunting, purchases, and gifts to consumption events in Amazonian urban households, so making comparisons is problematic. The closest reference is the study by Parry et al. (2014), in which only $12 \%$ of the households reported hunting, whereas we found that $42 \%$ of the consumption events reportedly originated from a household's own harvest. Although we can only speculate about the reasons for this divergence, at least two possibilities exist. First, our harvest estimate was directly linked to bushmeat-consumption events, whereas those authors asked about hunting behavior in general without linking it to specific events to supposedly avoid underreporting. Additionally, we 
approached interviewees through their children's schools to boost their confidence and decrease underreporting, so our strategy may have produced the desired result. Alternatively, investigating the origin of consumption events, as we did, might be less problematic than inquiring about hunting in general because that practice is illegal for urban residents. Furthermore, there are potential contextual differences between the locations studied here and those studied by Parry et al. (2014). Both studies investigated locations in forested landscapes and nearby protected areas, but the percentage of indigenous people in the Brazilian towns studied by Parry $(\sim 35 \%)$ was smaller than that of at least one of the Brazilian localities investigated by us (Tabatinga $=50 \%$ ) but equivalent to another (Atalaia do Norte $=35 \%$; see IBGE 2010). Although this might explain the observed differences, our results showed that people of indigenous origin were not more likely to harvest bushmeat than people of nonindigenous origin $\left(\mathrm{x}^{2}=\right.$ $0.078, p=0.779)$, although those born in forested environments were more likely to harvest bushmeat $\left(\chi^{2}=2.734, p=0.098\right)$.

Thus, the question remains as to why harvesting is locally common, and at least two points may provide an explanation. Presumably, a larger percentage of households harvest bushmeat instead of purchasing it because hunting is not only important for consumption but is also locally popular as a leisure activity (personal observation). Hunting may be combined with legal or illegal logging, an activity that is not common locally compared with other regions of the Amazon, but it provides additional income and is a source of firewood (Jaramillo and Rodríguez 2004). This overlap between subsistence, income generation, and recreation has been reported elsewhere, such as among Alaskan natives facing urbanization, in which the social, cultural, and psychological benefits of natural resource exploitation are prized along with the material contributions (Emery and Pierce 2005). Second and most importantly, those with less income in this study tended to harvest bushmeat more frequently than those with more income. Similarly, Parry et al. (2014) found that poorer households hunted more (23\%) than wealthier households (3\%), which tended to purchase bushmeat. Although we lack the data to estimate hunting costs, harvesting bushmeat might be cheaper than purchasing it or its alternatives, especially if hunting is done opportunistically in the pursuit of other activities such as fishing, recreation, and logging.

We are therefore left with the question of why the people in these towns consume bushmeat. The results indicate that both cultural and economic factors are important drivers of bushmeat consumption and preference as well as the range of accepted species, but one cultural aspect, Social relations, was consistently the strongest predictor.

\section{Cultural correlates}

Five proxies of culture were evaluated, including an objective indicator of people's origins as has been considered in several previous studies, as well as beliefs, attitudes, and social norms. Controlling for economic and other cultural correlates, the most important finding was that a person's origin, specifically selfdeclaring as indigenous, did not explain bushmeat consumption and preference, which contradicts other evidence. For instance, Fa et al. (2002b) observed disparities in bushmeat consumption between the Fang and Bubi ethnicities in Africa, and East et al. (2005) found that the Fang purchased more bushmeat than the other tribes, which primarily relied on fish and domestic meat. Other studies have classified origin more broadly. For example, Poulsen et al. (2009) evaluated whether being an immigrant, an indigene, or a foreigner influenced consumption. They found that autochthonous people consume $20 \%$ more bushmeat than migrant or foreign households as did Mgawe et al. (2012), who also observed that indigenes consume more bushmeat.

Three factors could explain why origin was unimportant to bushmeat consumption and preference in our sample. First, other studies have only investigated origin as a proxy of culture and this variable perhaps captured the effects of the other cultural aspects that we evaluated in more detail. Furthermore, in the towns we studied, there were ten different ethnicities whose diets presumably vary (Dufour 1991). Hence, a more detailed proxy of ethnicity could result in different outcomes, but it was impossible to evaluate specific ethnicities with our sample in contrast to other contexts where there are fewer ethnicities in one place (e.g., Fa et al. 2002b, East et al. 2005). Third, a factor that we did not consider, the variation in the length of time since migration into a town, could be more important than origin. Therefore, to test the robustness of our findings, we included residence time in some additional regressions (see Appendix I), but this variable did not predict consumption or preference.

In contrast to origin, other cultural factors were important predictors of consumption and preference for bushmeat. Above all, social relations were important for both; those who believed that bushmeat consumption is an important part of their cultural identity and that sharing bushmeat strengthens the links with kin and their territories of origin were more likely to consume bushmeat, to prefer it to other animal proteins, and to eat a broader range of wild species. Furthermore, controlling for confounding variables, Social relations was the strongest predictor among all of the other cultural and economic correlates.

The Social relations correlate is presumably a good predictor because of the general significance of food transference, and that of hunted meat in particular, in strengthening social bonds, gaining access to resources, and fostering political alliances. Food transferences in rural settings are well known, and although the evidence supporting the importance of rural-urban circuits to the maintenance of social networks and cultural identity is scant, it points in the same direction (Argounova-Low 2007). For instance, in Australia, rural-urban food sharing is essential to the preservation of indigenous identities and traditional rituals in urban areas (Foley 2005). Similarly, among urban dwellers in Greenland, seals are given as gifts to express the relationships people share with each other and to cement social bonds, even among westernized people (Nuttall 1991). In our sample, gifts were the second most important source of bushmeat, and informal interviews suggest that sharing wild meat is vital for strengthening social networks with family members and friends, some of whom live in rural or forested settings.

A previously established reason for food sharing among both rural and urban people is access to resources. For instance, in modern food sharing among the Inuit, resources are transferred during visits to pay for hospitality in town (Collings et al. 1998). Again, our informal interviews also suggest that gifts of bushmeat are a local form of repaying favors, particularly among indigene 
families who often reciprocate by assisting in the preparation of agricultural plots (personal observation). Additionally, as has been noted elsewhere (Wiessner 2002), sharing networks can also represent political strategies among those of indigenous origin, which enable the maintenance of political alliances by preserving group membership during residency in town or allowing rural inhabitants to gain prestige. Although our data do not support evaluations into whether rural-urban food sharing is more important for maintaining identity and social networks, paying for hospitality, accessing resources, or establishing political alliances, each of these factors probably plays a role, which makes them highly significant predictors of bushmeat consumption and preference.

The importance attributed to taboos, or informal social norms, also predicted the number of species a person would accept for consumption but not bushmeat consumption or preference. Moreover, taboos were better predictors of behavior and preference than attitudes toward the illegality of bushmeat consumption, which is an indicator of formal norms. Apparently, the weak enforcement of laws against bushmeat consumption and trade in the region is considered to be less relevant to the locals than cultural taboos. Accordingly, other authors have argued that where the capacity to enforce conservation regulations is limited, informal institutions may help (Tengö et al. 2007, Jones et al. 2008), for instance, by institutionalizing traditional practices such as taboos (Lingard et al. 2003). However, evaluations of cultural taboos are limited to the study of traditional populations in rural environments (Colding and Folke 2001) because informal institutions are more common where there is relatively constant group membership, long-term residency, and heavy reliance on natural resources (Jones et al. 2008). Thus, the exposure to modern living in urban areas is expected to erode bushmeat-related taboos (Anoliefo et al. 2003). However, our results partially challenge this view by demonstrating that taboos are important in urban settings, which suggests that cultural transmission does not necessarily end with modernization as has previously been claimed (Luzar et al. 2012). Furthermore, although taboos may not reduce bushmeat consumption in general, they might be partially applied as segment taboos, e.g., a ban on one or more species at a specific time depending on sex, age, social status, or reproductive condition (Colding and Folke 2001, Tengö et al. 2007). Indeed, in the Amazon, taboos are often associated with illnesses and conditions unique to women, particularly maternity and menstrual periods (Begossi et al. 2004), and our findings indicate that, on average, women considered taboos to be more important than the men did. While these differences were not significant, women consistently reported a lower level of species acceptability than men as would be expected under local taboos. However, taboos only impact behavior if they are adhered to (Colding and Folke 2001), and we failed to find a strong relationship between taboos and bushmeat consumption in the previous month. However, because taboos in the Amazon are often associated with temporal prescriptions related to personal conditions (Begossi et al. 2004), our one-shot sample was not sufficient for making robust inferences about fluctuations in consumption.

The last psychosocial indicator that we evaluated was the belief that bushmeat is becoming scarcer, which was associated with a lower probability of consuming bushmeat but not with the preference for bushmeat or the number of species accepted. This result is important because there is a growing recognition that, above all, the conservation of natural systems depends on understanding behavior so that policy makers can devise strategies to promote behavioral change (St. John et al. 2014). Insofar as people respond to the perception that bushmeat is unsustainable with decreased consumption, outreach campaigns aimed at raising the awareness of local people may positively impact species conservation. However, it could be argued that the perception of bushmeat scarcity might be capturing a price effect because prices tend to increase in locations where bushmeat is scarcer thus decreasing the likelihood of bushmeat consumption. All of our interviewees, however, lived in the same region and in similar locations, so they would have been encountering equivalent bushmeat prices and scarcity. Even so, we found individual variation in beliefs about scarcity, giving credence to our interpretation.

\section{Economic correlates}

Three economic indicators were assessed: two objective aspects (cash income and wealth) and one attitudinal indicator (price perception). All were correlated with proxies of bushmeat alternatives, although their effects were always smaller than Social relations.

Higher income was associated with a lower probability that a person would consume bushmeat, but it did not significantly predict the preference for bushmeat or the number of species that was likely to be eaten. Similarly, some studies conducted in African towns have also observed that higher income levels are associated with less bushmeat consumption (Albrechtsen et al. 2005). Others, however, have indicated that people with higher incomes consume more bushmeat in African towns (East et al. 2005) and that traded bushmeat is a luxury good among Africans living in Europe (Chaber et al. 2010). These contrasting results, which have also been observed in rural locations (Coad et al. 2010, Godoy et al. 2010, Kümpel et al. 2010, Rentsch and Damon 2013), could be explained by the variety of conditions found across study locations, such as bushmeat availability, prices, and people's preferences. There are four plausible explanations for why those with lower incomes are more likely to eat bushmeat in this study.

First, in contrast to the evidence from Africa, the bushmeat in our sample was mostly supplied by family members who had hunted or received the meat as a gift rather than purchased it. Brashares and colleagues (2011:13934) argued that "in urban areas, the dynamics of wildlife consumption would be dominated by consumer income effects because the shortage of local wildlife made hunting an unrealistic option." However, in this study, urban residents were able to harvest bushmeat from the surrounding forests or to receive it as a gift through their social networks. Thus, bushmeat could provide an accessible and perhaps cheaper source of animal protein. Although we lack the data necessary to rigorously assess the costs and benefits of harvesting bushmeat, S. Hernandez (unpublished data) found the cost of hunting in the region, including only the necessary supplies, e.g., ammunition, petrol for transport, and ice for preservation, to be about US $\$ 0.17$ per kilogram, which is much lower than the cost of locally purchased domestic meat, such as chicken $($ Avg. $=$ US\$1.24) or cattle $($ Avg. $=$ US\$6.20), according to recently published prices (van Vliet et al. 2014). However, we 
caution that this unpublished estimate of hunting costs neglects the cost of labor and the probability of a successful hunt, factors that would likely increase the cost.

Prices could be a second explanatory factor, because similar outcomes, i.e., poorer individuals consume bushmeat more frequently than wealthier individuals, have been observed where bushmeat is cheaper than other animal proteins (Albrechtsen et al. 2005). In contrast, in African locations where bushmeat is more expensive than frozen chicken, poorer people consume less bushmeat (Wilkie et al. 2005, Coad et al. 2010). Therefore, our results appear to contradict previous evidence because the smoked bushmeat (the cheapest form) sold in the towns is, on average, at least three times more expensive than frozen chicken (van Vliet et al. 2014). This apparent contradiction could be explained by the fact that bushmeat mostly comes from harvesting and gifts, which are presumably less expensive alternatives than purchasing.

Third, in this region, the bushmeat trade is sourced by both specialized hunters, who sell approximately $95 \%$ of their harvest for cash income, and by non-specialized hunters who sell approximately $25 \%$ of their harvest for trade and consume the rest (Quiceno-Mesa et al. 2014). Thus, although we did not ask whether people traded bushmeat because of the sensitivity of this question, bushmeat appears to not only provide a source of food but occasional cash income, a factor that may help explain why poorer individuals consume bushmeat more frequently in our sample.

Fourth, the finding could have arisen because most people prefer other animal proteins to bushmeat, which would explain why the worst off were more likely to consume bushmeat. Other authors (Godoy 2001, Demmer et al. 2002) have argued that higher income should be associated with lower consumption when bushmeat is not the preferred animal protein, as we found. In contrast, East et al. (2005) observed that bushmeat consumption increased with income in West African towns, even though fresh fish was the preferred animal protein. However, fresh bushmeat in West Africa is more preferred by people than in this study, and preference and consumption were highly positively related in contrast to our observation that consumption and preference were not highly correlated. Other comparisons with prior evidence are hindered because studies of preference often aggregate it with consumption even though the indicators may overlap or contrast ( $\mathrm{Fa}$ et al. $2002 b$ ) as suggested by our evidence.

Unlike income, wealth, as estimated through asset holdings, was not associated with bushmeat consumption, but greater wealth was significantly correlated with a lower likelihood of preferring bushmeat over other animal proteins. The first finding might either support or contradict previous evidence because, as with income, the association between wealth and bushmeat consumption is highly variable across locations. In urban contexts, previous studies have reported that richer individuals consume either more (Fa et al. 2009, Brashares et al. 2011) or less (van Vliet et al. 2015b) bushmeat, variability that has also been observed in rural contexts (de Merode et al. 2004, Fa et al. 2009, Godoy et al. 2010, Brashares et al. 2011, Jenkins et al. 2011). In studies based in urban areas in which greater wealth has been associated with increased consumption, bushmeat is expensive, whereas the opposite has occurred when a negative correlation has been observed. In our study, however, wealth did not predict consumption during the previous month, perhaps because, controlling for other factors, accumulated wealth is a poor indicator of consumption over the short term; income may be more appropriate in this regard.

The second finding that poorer individuals are more likely to prefer bushmeat than richer individuals, is similar to the pattern that has already been discussed for income. In this case, however, accumulated wealth and preference for bushmeat are both longer term indicators, so they are more likely to be associated. This evidence suggests that bushmeat was probably an inferior good in the Amazonian towns we studied, where it is consumed by people with fewer alternatives in contrast to certain African towns in which it is a luxury good (Cowlishaw et al. 2005). However, this case is similar to Madagascar, where fish and domestic proteins were preferred and bushmeat consumption peaked among the poorest households (Jenkins et al. 2011). Alternatively, the role of bushmeat might differ between poor and wealthy households, but we cannot test this claim given our small sample size. For instance, harvested bushmeat may be a necessity to the poor, whereas purchased bushmeat represents a luxury that adds to the variety of the diets of the richer households or is consumed on special occasions, such as feasts.

Regarding the last economic indicator, i.e., Price perception, our findings show that those for whom food prices play an important role in food choice are less selective. They may thus accept any bushmeat species for consumption, as indicated by Price perception, which was significantly associated with species acceptability.

\section{CONCLUSIONS}

We began this article by proposing that cultural aspects should be more important than economic correlates in explaining bushmeat consumption and preference in Amazonian towns. By showing that certain cultural factors are indeed the stronger predictors and, above all, by demonstrating the importance of social relations, we supported our hypothesis. However, our results also showed that economic attributes and other cultural indicators were important, depending on the bushmeat proxy evaluated, while people's origin was unimportant.

The findings of this study advance the current literature on urban bushmeat consumption, which has predominantly focused on economic drivers and objective indicators of origin but has seldom modeled the effects of other cultural attributes, such as beliefs, attitudes, and social norms. The importance of the attitudes and social norms investigated in this study suggests that some contradictory findings in the current literature perhaps arose from a failure to incorporate factors that are stronger predictors of bushmeat consumption and preferences, even in urban settings. More importantly, such a failure may hinder the design of effective conservation strategies and management practices. For instance, because bushmeat consumption in the Amazonian towns that we studied appears to be primarily driven by social factors, strategies to provide economic incentives to encourage the availability of less expensive animal proteins ( $\mathrm{Fa}$ et al. 2009) will likely have limited impact. However, because an awareness of bushmeat scarcity tends to be associated with a decrease in bushmeat consumption, combining economic incentives with public-awareness campaigns, as suggested by 
Milner-Gulland and Bennett (2003), represents a good strategy, especially because these campaigns have already been shown to work (Steinmetz et al. 2014). Additionally, strategies that rely on informal institutions, such as taboos, or are framed with local taboos in mind may receive greater acceptance than governmental laws, as has been previously argued (Lingard et al. 2003).

In summary, our most important conclusion is that more detailed evaluations of subjective cultural aspects, such as people's beliefs, attitudes, and social norms, will improve our understanding of the drivers of bushmeat consumption and preference and, consequently, enable us to design more effective and legitimate conservation and management strategies for wild species. Because the implications of urban consumption, even when only occasional, to the sustainability of wild game are significant, knowledge of the factors that drive human behavior is vital.

Responses to this article can be read online at: http://www.ecologyandsociety.org/issues/responses. $\mathrm{php} / 7771$

\section{Acknowledgments:}

This work has been funded by USAID and UKAID through CIFOR's Bushmeat research initiative. We thank Annie Julissa Escobedo Grandez, Juana Cabrera, Diana Gil Bora, Ellen Anjos Camilo, and Juliana Silva for participating in the interviews; the schools that assisted us in the study; Ana Catarina Cardoso Luz, Alice Dantas Brites, and Patricia Carignano Torres for comments on earlier drafts; and the people of the four towns who patiently answered our questions.

\section{LITERATURE CITED}

Ajzen, I. 1991. The theory of planned behavior. Organizational Behavior and Human decision Processes 50:179-211. http://dx.doi. org/10.1016/0749-5978(91)90020-T

Ajzen, I. 2005. Attitudes, personality and behaviour. McGraw-Hill International, Maidenhead, UK.

Albarracin, D., B. T. Johnson, and M. P. Zanna. 2014. The handbook of attitudes. Psychology Press, New York, New York, USA.

Albrechtsen, L., J. E. Fa, B. Barry, and D. W. Macdonald. 2005. Contrasts in availability and consumption of animal protein in Bioko Island, West Africa: the role of bushmeat. Environmental Conservation 32:340-348. http://dx.doi.org/10.1017/S0376892906002694

Altman, M., editor. 2006. Handbook of contemporary behavioral economics: foundations and developments. M. E. Sharpe, Armonk, New York, USA.

Anoliefo, G. O., O. S. Isikhuemhen, and N. R. Ochije. 2003. Environmental implications of the erosion of cultural taboo practices in Awka-South local government area of Anambra State, Nigeria: 1. Forests, trees, and water resource preservation. Journal of Agricultural and Environmental Ethics 16:281-296. http://dx.doi.org/10.1023/A:1023680117717
Argounova-Low, T. 2007. Close relatives and outsiders: village people in the city of Yakutsk, Siberia. Arctic Anthropology 44:51-61. http://dx.doi.org/10.1353/arc.2011.0072

Axelson, M. L. 1986. The impact of culture on food-related behavior. Annual Review of Nutrition 6:345-363. http://dx.doi. org/10.1146/annurev.nu.06.070186.002021

Baía-Júnior, P. C., D. A. Guimarães, and Y. Le Pendu. 2010. Nonlegalized commerce in game meat in the Brazilian Amazon: a case study. Revista de Biologia Tropical 58:1079-1088.

Begossi, A., N. Hanazaki, and R. M. Ramos. 2004. Food chain and the reasons for fish good taboos among Amazonian and Atlantica Forest Fishers (Brazil). Ecological Applications 14:1334-1343. http://dx.doi.org/10.1890/03-5072

Bennett, E. L., and J. G. Robinson. 2000. Hunting of wildlife in tropical forests: implications for biodiversity and forest peoples. Environmental Department Working Paper No. 76. The World Bank, Washington, D.C., USA.

Bitanyi, S., M. Nesje, L. J. M. Kusiluka, S. W. Chenyambuga, and B. P. Kaltenborn. 2012. Awareness and perceptions of local people about wildlife hunting in western Serengeti communities. Tropical Conservation Science 5:208-224.

Bodmer, R. E., and E. P. Lozano. 2001. Rural development and sustainable wildlife use in Peru. Conservation Biology 15:1163-1170. http://dx.doi.org/10.1046/j.1523-1739.2001.0150041163. $\underline{\mathrm{X}}$

Brashares, J. S., C. D. Golden, K. Z. Weinbaum, C. B. Barrett, and G. V. Okello. 2011. Economic and geographic drivers of wildlife consumption in rural Africa. Proceedings of the National Academy of Sciences 108:13931-13936. http://dx.doi.org/10.1073/ pnas. 1011526108

Chaber, A.-L., S. Allebone-Webb, Y. Lignereux, A. A. Cunningham, and J. Marcus Rowcliffe. 2010. The scale of illegal meat importation from Africa to Europe via Paris. Conservation Letters 3:317-321. http://dx.doi.org/10.1111/j.1755-263X.2010.00121. $\underline{x}$

Coad, L., K. Abernethy, A. Balmford, A. Manica, L. Airey, and E. J. Milner-Gulland. 2010. Distribution and use of income from bushmeat in a rural village, Central Gabon. Conservation Biology 24:1510-1518. http://dx.doi.org/10.1111/j.1523-1739.2010.01525. $\underline{\mathrm{x}}$

Colding, J., and C. Folke. 2001. Social taboos: "invisible" systems of local resources management and biological conservation. Ecological Applications 11:584-600.

Collings, P., G. Wenzel, and R. G. Condon. 1998. Modern food sharing networks and community integration in the central Canadian Arctic. Arctic 51:301-314. http://dx.doi.org/10.14430/ $\underline{\operatorname{arctic} 1073}$

Cowlishaw, G., S. Mendelson, and J. M. Rowcliffe. 2005. Structure and operation of a bushmeat commodity chain in Southwestern Ghana. Conservation Biology 19:139-149.

Cronbach, L. J., and R. J. Shavelson. 2004. My current thoughts on coefficient alpha and successor procedures. Educational and Psychological Measurement 64:391-418. http://dx.doi. org/10.1177/0013164404266386 
de Merode, E., K. Homewood, and G. Cowlishaw. 2004. The value of bushmeat and other wild foods to rural households living in extreme poverty in Democratic Republic of Congo. Biological Conservation 118:573-581. http://dx.doi.org/10.1016/j.biocon.2003.10.005

Demmer, J., R. Godoy, D. Wilkie, H. Overman, M. Taimur, K. Fernando, R. Gupta, K. McSweeney, N. Brokaw, S. Sriram, and T. Price. 2002. Do levels of income explain differences in game abundance? An empirical test in two Honduran villages. Biodiversity and Conservation 11:1845-1868. http://dx.doi. org/10.1023/A:1020305903156

Drewnowski, A. 1997. Taste preferences and food intake. Annual Review of Nutrition 17:237-253. http://dx.doi.org/10.1146/ annurev.nutr.17.1.237

Dufour, D. L. 1991. Diet and nutritional status of Amerindians: a review of the literature. Cadernos de Saúde Pública 7:481-502. http://dx.doi.org/10.1590/s0102-311x1991000400003

East, T., N. F. Kümpel, E. J. Milner-Gulland, and J. M. Rowcliffe. 2005. Determinants of urban bushmeat consumption in Río Muni, Equatorial Guinea. Biological Conservation 126:206-215. http://dx.doi.org/10.1016/j.biocon.2005.05.012

Emery, M. R., and A. R. Pierce. 2005. Interrupting the telos: locating subsistence in contemporary US forests. Environment and Planning A 37:981-993. http://dx.doi.org/10.1068/a36263

Fa, J. E., L. Albrechtsen, P. J. Johnson, and D. W. Macdonald. 2009. Linkages between household wealth, bushmeat and other animal protein consumption are not invariant: evidence from Rio Muni, Equatorial Guinea. Animal Conservation 12:599-610. http://dx.doi.org/10.1111/j.1469-1795.2009.00289.x

Fa, J. E., J. Juste, R. W. Burn, and G. Broad. 2002b. Bushmeat consumption and preferences of two ethnic groups in Bioko Island, West Africa. Human Ecology 30:397-416. http://dx.doi. org/10.1023/A:1016524703607

Fa, J. E., C. A. Peres, and J. Meeuwig. 2002a. Bushmeat exploitation in tropical forests: an intercontinental comparison. Conservation Biology 16:232-237. http://dx.doi.org/10.1046/ j.1523-1739.2002.00275.x

Foley, W. 2005. Tradition and change in urban indigenous food practices. Postcolonial Studies 8:25-44. http://dx.doi. org/10.1080/13688790500134356

Gavin, M. C., and G. J. Anderson. 2007. Socioeconomic predictors of forest use values in the Peruvian Amazon: a potential tool for biodiversity conservation. Ecological Economics 60:752-762. http://dx.doi.org/10.1016/j.ecolecon.2006.01.010

Gelman, A. 2008. Scaling regression inputs by dividing by two standard deviations. Statistics in Medicine 27:2865-2873. http:// dx.doi.org/10.1002/sim.3107

Gelman, A., and J. Hill. 2007. Data analysis using regression and multilevel/hierarchical models. Cambridge University Press, New York, New York, USA. http://dx.doi.org/10.1017/cbo9780511790942

Girón, Y. A. P. 2010. Construyendo la historia ambiental de Leticia através de la pesca (1950-2008). Territórios e Fronteiras 3:97-104.

Godoy, R., E. A. Undurraga, D. Wilkie, V. Reyes-García, T. Huanca, W. R. Leonard, T. McDade, S. Tanner, V. Vadez, and
TAPS Bolivia Study Team. 2010. The effect of wealth and real income on wildlife consumption among native Amazonians in Bolivia: estimates of annual trends with longitudinal household data (2002-2006). Animal Conservation 13:265-274. http://dx.doi. org/10.1111/j.1469-1795.2009.00330.x

Godoy, R. A. 2001. Indians, markets and rainforests. Columbia University Press, New York, New York, USA.

Government of Brazil. 2014. Áreas de Livre Comércio de Tabatinga. Suframa, Manaus, Brasil.

Government of Colombia. 2008. Municipio de Puerto Nariño, Departamento de Amazonas: Plan de Desarollo 2008-2011. Coordinación General del Plan de Desarollo, Alcaldía Municipal de Puerto Narinõ, Puerto Nariño, Colombia.

Government of Colombia. 2015. Municipio de Puerto NariñoAmazonas - Plan de desarrollo municipal 2012- 2015. Puerto Nariño, Colombia.

Hamilton, L. 2012. Statistics with STATA: Version 12. Cengage Learning, Boston, Massachusetts, USA.

Heberlein, T. A. 2012. Navigating environmental attitudes. Oxford University Press, Oxford, UK. http://dx.doi.org/10.1093/acprof: oso/9780199773329.001.0001

Higuchi, M. I. G., M. G. A. Calegare, M. L. S. G. Porto, M. B. D. F. Lima, and R. M. Feitosa. 2011. Diagnóstico socioambiental do município de Atalaia do Norte / AM. INPA, Manaus, Brazil.

Hurtado, L. M. 2005. Pobreza y marginalidad urbanas en la Amazonia. Un estudio de caso de los asentamientos ubicados en zonas inundables. Universidad Nacional de Colombia, Leticia, Colombia.

Instituto Brasileiro de Geografia e Estatística (IBGE). 2010. Indicadores Sociais Municipais: uma análise dos resultados do universo do Censo Demográfico. IBGE, Rio de Janeiro, Brasil.

Instituto Brasileiro de Geografia e Estatística (IBGE). 2013. Cidades@. IBGE, Rio de Janeiro, Brasil.

Jaramillo, D. O., and C. A. G. Rodríguez. 2004. Control social y coordinacion: un camino hacia la sostenibilidad amazónica: caso maderas del trapecio amazónico. Universidad Nacional de Colombia, Leticia, Colombia.

Jenkins, R. K. B., A. Keane, A. R. Rakotoarivelo, V. Rakotomboavonjy, F. H. Randrianandrianina, H. J. Razafimanahaka, S. R. Ralaiarimalala, and J. P. G. Jones. 2011. Analysis of patterns of bushmeat consumption reveals extensive exploitation of protected species in eastern Madagascar. PLoS ONE 6(12): e27570. http://dx.doi.org/10.1371/journal.pone.0027570

Johns, R. 2010. Likert items and scales. University of Essex, Colchester, UK.

Jolliffe, I. T. 2002. Principal component analysis. Springer, Secaucus, New Jersey, USA.

Jones, J. P. G., M. M. Andriamarovololona, and N. Hockley. 2008. The importance of taboos and social norms to conservation in Madagascar. Conservation Biology 22:976-986. http://dx.doi. org/10.1111/j.1523-1739.2008.00970.x

Kaltenborn, B. P., J. W. Nyahongo, and K. M. Tingstad. 2005. The nature of hunting around the western corridor of Serengeti 
National Park, Tanzania. European Journal of Wildlife Research 51:213-222. http://dx.doi.org/10.1007/s10344-005-0109-9

Kümpel, N. F., E. Milner-Gulland, G. Cowlishaw, and J. M. Rowcliffe. 2010. Incentives for hunting: the role of bushmeat in the household economy in rural Equatorial Guinea. Human Ecology 38:251-264. http://dx.doi.org/10.1007/s10745-010-9316-4

Lee, T. M., N. S. Sodhi, and D. M. Prawiradilaga. 2009. Determinants of local people's attitude toward conservation and the consequential effects on illegal resource harvesting in the protected areas of Sulawesi (Indonesia). Environmental Conservation 36:157-170. http://dx.doi.org/10.1017/S0376892909990178

Lindsey, P. A., G. Balme, M. Becker, C. Begg, C. Bento, C. Bocchino, A. Dickman, R. W. Diggle, H. Eves, P. Henschel, et al. 2013. The bushmeat trade in African savannas: impacts, drivers, and possible solutions. Biological Conservation 160:80-96. http:// dx.doi.org/10.1016/j.biocon.2012.12.020

Lingard, M., N. Raharison, E. Rabakonandrianina, J.-A. Rakotoarisoa, and T. Elmqvist. 2003. The role of local taboos in conservation and management of species: the radiated tortoise in Southern Madagascar. Conservation and Society 1:223-246.

Lunt, P. 2006. Rational choice theory versus cultural theory. Pages 326-339 in M. Altman, editor. Handbook of contemporary behavioral economics: foundations and developments. M. E. Sharpe, Armonk, New York, USA.

Luz, A. C. 2012. The role of acculturation in indigenous peoples' hunting patterns and wildelife availability: The case of the Tsimane' in the Bolivian Amazon. Institut de Ciència i Tecnologia Ambientals. Universitat Autònoma de Barcelona, Barcelona, Spain.

Luzar, J. B., K. M. Silvius, and J. M. V. Fragoso. 2012. Church affiliation and meat taboos in indigenous communities of Guyanese Amazonia. Human Ecology 40:833-845. http://dx.doi. org/10.1007/s10745-012-9521-4

MacFayden, A. J. 2006. Beliefs in behavioral and neoclassical economics. Pages 183-201 in M. Altman, editor. Handbook of contemporary behavioral economics: foundations and developments. M. E. Sharpe, Armonk, New York, USA.

Magalhães, M. 2000. O narcotráfico. Publifolha, São Paulo, Brasil.

Manfredo, M. J. 2008. Who cares about wildlife? Springer-Verlag, New York, New York, USA. http://dx.doi.org/10.1007/978-0-387-77040-6

Manfredo, M. J., T. Teel, and A. Bright, editors. 2004. Application of the concepts of values and attitudes in human dimensions of natural resources research. Modern Litho, Jefferson, Missouri, USA.

Mankiw, N. G. 2009 Principles of microeconomics. South-Western Cengage Learning, Mason, Ohio, USA.

Mbete, R. A., H. Banga-Mboko, P. Racey, A. Mfoukou-Ntsakala, I. Nganga, C. Vermeulen, J.-L. Doucet, J.-L. Hornick, and P. Leroy. 2011. Household bushmeat consumption in Brazzaville, the Republic of the Congo. Tropical Conservation Science 4:187-202.
Mgawe, P., M. Borgerhoff-Mulder, T. Caro, A. Martin, and C. Kiffner. 2012. Factors affecting bushmeat consumption in the Katavi-Rukwa ecosystem of Tanzania. Tropical Conservation Science 5:446-462.

Milner-Gulland, E. J., and E. L. Bennett. 2003. Wild meat: the bigger picture. Trends in Ecology \& Evolution 18:351-357. http:// dx.doi.org/10.1016/s0169-5347(03)00123-X

Nardoto, G. B., R. S. S. Murrieta, L. E. G. Prates, C. Adams, M. E. P. E. Garavello, T. Schor, A. De Moraes, F. D. Rinaldi, J. G. Gragnani, E. A. F. Moura, P. J. Duarte-Neto, and L. A. Martinelli. 2011. Frozen chicken for wild fish: nutritional transition in the Brazilian Amazon region determined by carbon and nitrogen stable isotope ratios in fingernails. American Journal of Human Biology 23:642-650. http://dx.doi.org/10.1002/ajhb.21192

Nascimento, H. S. 2001. Relatório sobre o impacto da exploração, comercial e de subsistência, de recursos da fauna por não índios, dentro da Área Indigena Vale do Javari, Amazonas. CTI-FUNAI, Tabatinga, Brasil.

Nasi, R., A. Taber, and N. Van Vliet. 2011. Empty forests, empty stomachs? Bushmeat and livelihoods in the Congo and Amazon Basins. International Forestry Review 13:355-368. http://dx.doi. org/10.1505/146554811798293872

Naughton-Treves, L. 2002. Wild animals in the garden: conserving wildlife in Amazonian agroecosystems. Annals of the Association of American Geographers 92:488-506. http://dx.doi. org/10.1111/1467-8306.00301

Nuttall, M. 1991. Sharing and the ideology of subsistence in a Greenlandic sealing community. Polar Record 27:217-222. http:// dx.doi.org/10.1017/S0032247400012602

Oppenheim, A. N. 1966. Questionnaire design and attitude measurement. Basic Books, New York, New York, USA.

Padoch, C., E. Brondizio, S. Costa, M. Pinedo-Vasquez, R. R. Sears, and A. Siqueira. 2008. Urban forest and rural cities: multisited households, consumption patterns, and forest resources in Amazonia. Ecology and Society 13(2):2. [online] URL: http:// www.ecologyandsociety.org/vol13/iss2/art2/

Parry, L., J. Barlow, and H. Pereira. 2014. Wildlife harvest and consumption in Amazonia's urbanized wilderness. Conservation Letters 7:565-574. http://dx.doi.org/10.1111/conl.12151

Parry, L., J. Barlow, and C. A. Peres. 2009. Allocation of hunting effort by Amazonian smallholders: implications for conserving wildlife in mixed-use landscapes. Biological Conservation 142:1777-1786. http://dx.doi.org/10.1016/j.biocon.2009.03.018

Patton, J. Q. 2005. Meat sharing for coalitional support. Evolution and Human Behavior 26:137-157. http://dx.doi.org/10.1016/j. evolhumbehav.2004.08.008

Peres, C. A., and H. S. Nascimento. 2006. Impact of game hunting by the Kayapó of south-eastern Amazonia: implications for wildlife conservation in tropical forest indigenous reserves. Biodiversity \& Conservation 15:2627-2653. http://dx.doi. org/10.1007/s10531-005-5406-9

Pezzuti, J. C. B., J. P. Lima, D. F. da Silva, and A. Begossi. 2010. Uses and taboos of turtles and tortoises along Rio Negro, 
Amazon Basin. Journal of Ethnobiology 30:153-168. http://dx. doi.org/10.2993/0278-0771-30.1.153

Poulsen, J. R., C. J. Clark, G. Mavah, and P. W. Elkan. 2009. Bushmeat supply and consumption in a tropical logging concession in Northern Congo. Conservation Biology 23:1597-1608. http://dx.doi.org/10.1111/j.1523-1739.2009.01251. $\underline{\mathrm{X}}$

Quiceno-Mesa, M. P., D. Cruz-Antia, N. van Vliet, Aquino, L. J. Neves de Aquino, and T. Schor. 2014. La invisibilidad de las cadenas comerciales de carne de monte en la Triple Frontera Amazónica entre Colombia, Perú y Brasil. Revista Colombia Amazonica 7:51-71.

Rabe-Hesketh, S., and A. Skrondal. 2012. Multilevel and longitudinal modeling using Stata. Stata Press, College Station, Texas, USA.

Redford, K. H., and J. G. Robinson. 1987. The game of choice: patterns of Indian and colonist hunting in the Neotropics. American Anthropologist 89:650-667. http://dx.doi.org/10.1525/ aa.1987.89.3.02a00070

Rentsch, D., and A. Damon. 2013. Prices, poaching, and protein alternatives: an analysis of bushmeat consumption around Serengeti National Park, Tanzania. Ecological Economics 91:1-9. http://dx.doi.org/10.1016/j.ecolecon.2013.03.021

Ricardo, B., and F. Ricardo. 2011. Povos indígenas no Brasil: 2006/2010. Instituto Socioambiental, São Paulo, Brasil.

Ross, E. B., M. L. Arnott, E. B. Basso, S. Beckerman, R. L. Carneiro, R. G. Forbis, K. R. Good, K.-E. Jensen, A. Johnson, J. Kaplinski, R. S. Khare, O. F. Linares, P. S. Martin, B. Nietschmann, G. T. Nurse, N. J. Pollock, I. Sahai, K. Clarkson Taylor, D. Turton, W. T. Vickers, and W. E. Wetterstrom. 1978. Food taboos, diet, and hunting strategy: the adaptation to animals in Amazon cultural ecology. Current Anthropology 19:1-36. http:// dx.doi.org/10.1086/201999

Rushton, J., R. Viscarra, C. Viscarra, F. Basset, R. Baptista, and D. Brown. 2005. How important is bushmeat consumption in South America: now and in the future? ODI Wildlife Policy Briefing 11.

Schenck, M., E. Nsame Effa, M. Starkey, D. Wilkie, K. Abernethy, P. Telfer, R. Godoy, and A. Treves. 2006. Why people eat bushmeat: results From two-choice, taste tests in Gabon, Central Africa. Human Ecology 34:433-445. http://dx.doi.org/10.1007/ $\underline{\text { s10745-006-9025-1 }}$

Schor, T., R. R. Marinho, D. P. da Costa, and J. A. de Oliveira. 2014. Cities, rivers and urban network in the Brazilian Amazon. Brazilian Geographical Journal 5:258-276.

St. John, F. A. V., A. M. Keane, J. P. G. Jones, and E. J. MilnerGulland. 2014. Robust study design is as important on the social as it is on the ecological side of applied ecological research. Journal of Applied Ecology 51:1479-1485. http://dx.doi.org/10.1111/136$\underline{5-2664.12352}$

Steinmetz, R., S. Srirattanaporn, J. Mor-Tip, and N. Seuaturien. 2014. Can community outreach alleviate poaching pressure and recover wildlife in South-East Asian protected areas? Journal of Applied Ecology 51:1469-1478. http://dx.doi.org/10.1111/1365-2664.12239
Stoop, I. A. L. 2004. Surveying nonrespondents. Field Methods 16:23-54. http://dx.doi.org/10.1177/1525822X03259479

Suárez, E., M. Morales, R. Cueva, V. Utreras Bucheli, G. ZapataRíos, E. Toral, J. Torres, W. Prado, and J. Vargas Olalla. 2009. Oil industry, wild meat trade and roads: indirect effects of oil extraction activities in a protected area in north-eastern Ecuador. Animal Conservation 12:364-373. http://dx.doi.org/10.1111/ j.1469-1795.2009.00262.x

Tadie, D., and A. Fischer. 2013. Hunting, social structure and human-nature relationships in Lower Omo, Ethiopia: people and wildlife at a crossroads. Human Ecology 41:447-457. http://dx.doi. org/10.1007/s10745-012-9561-9

Tengö, M., K. Johansson, F. Rakotondrasoa, J. Lundberg, J.-A. Andriamaherilala, J.-A. Rakotoarisoa, and T. Elmqvist. 2007. Taboos and forest governance: informal protection of hot spot dry forest in southern Madagascar. AMBIO: A Journal of the Human Environment 36:683-691. http://dx.doi.org/10.1579/0044-7447 (2007)36[683:tafgip]2.0.co:2

Tucker, B. 2007. Applying behavioral ecology and behavioral economics to conservation and development planning: an example from the Mikea forest, Madagascar. Human Nature 18:190-208. http://dx.doi.org/10.1007/s12110-007-9017-x

Valle, M. d. R. d. 2006. Reserva de Desenvolvimento Sustentável Cujubim. Conservação Internacional, Brasília.

van Vliet, N. and P. Mbazza. 2011. Recognizing the multiple reasons for bushmeat consumption in urban areas: a necessary step toward the sustainable use of wildlife for food in Central Africa. Human Dimensions of Wildlife 16:45-54. http://dx.doi. org/10.1080/10871209.2010.523924

van Vliet, N., C. Nebesse, S. Gambalemoke, D. Akaibe, and R. Nasi. 2012. The bushmeat market in Kisangani, Democratic Republic of Congo: implications for conservation and food security. Oryx 46:196-203. http://dx.doi.org/10.1017/S0030605311000202

van Vliet, N., C. Nebesse, and R. Nasi. 2015b. Bushmeat consumption among rural and urban children from Province Orientale, Democratic Republic of Congo. Oryx 49:165-174. http://dx.doi.org/10.1017/S0030605313000549

van Vliet, N., M. P. Quiceno Mesa, D. Cruz-Antia, L. J. Neves de Aquino, J. Moreno, and R. Nasi. 2014. The uncovered volumes of bushmeat commercialized in the Amazonian trifrontier between Colombia, Peru \& Brazil. Ethnobiology and Conservation 3(7).

van Vliet, N., M. P. Quiceno-Mesa, D. Cruz-Antia, L. Tellez, C. Martins, E. Haiden, M. R. Oliveira, C. Adams, C. Morsello, L. Valencia, T. Bonilla, B. Yagüe, and R. Nasi. 2015a. From fish and bushmeat to chicken nuggets: the nutrition transition in a continuum from rural to urban settings in the Tri Frontier Amazon region. Ethnobiology and Conservation 4:6. http://dx.doi. org/10.15451/ec2015-7-4.6-1-12

Walters, G., S. Touladjan, and L. Makouka. 2014. Integrating cultural and conservation contexts of hunting: the case of the plateau Bateke savvanas of Gabon. African Study Monographs Supplementary Issue 35:99-128. 
Wiessner, P. 2002. Hunting, healing, and hxaro exchange: a longterm perspective on !Kung (Ju/'hoansi) large-game hunting. Evolution and Human Behavior 23:407-436. http://dx.doi. org/10.1016/S1090-5138(02)00096-X

Wilkie, D. S., and J. F. Carpenter. 1999. Bushmeat hunting in the Congo Basin: an assessment of impacts and options for mitigation. Biodiversity \& Conservation 8:927-955. http://dx.doi. org/10.1023/A:1008877309871

Wilkie, D. S., and R. A. Godoy. 2001. Income and price elasticities of bushmeat demand in lowland Amerindian societies. Conservation Biology 15:761-769. http://dx.doi.org/10.1046/ j.1523-1739.2001.015003761.x

Wilkie, D. S., M. Starkey, K. Abernethy, E. N. Effa, P. Telfer, and R. Godoy. 2005. Role of prices and wealth in consumer demand for bushmeat in Gabon, Central Africa. Conservation Biology 19:268-274. http://dx.doi.org/10.1111/j.1523-1739.2005.00372.x

Willcox, A. S., and D. M. Nambu. 2007. Wildlife hunting practices and bushmeat dynamics of the Banyangi and Mbo people of Southwestern Cameroon. Biological Conservation 134:251-261. http://dx.doi.org/10.1016/j.biocon.2006.08.016

Yagüe, B. 2013. Haciendo comestible la ciudad: Los indígenas urbanos de Leticia y sus redes desde la soberanía alimentaria. Thesis. Universidad Nacional de Colombia, Leticia, Colombia.

Yagüe, B. 2014. Hacer "comestible" la ciudad. Las redes como estrategias alimentarias de los indígenas urbanos de Leticia, Amazonia colombiana. Revista Colombiana de Antropología 50:141-166.

Zarate, C. 2008. Fronteras en la globalización: localidad, biodiversidad y comercio en la Amazonia. Fundación Konrad Adenauer, Bogotá, Colombia.

Zuur, A. F., E. N. Ieno, N. Walker, A. A. Saveliev, and G. M. Smith. 2009. Mixed effects models and extensions in ecology with $R$. Springer-Verlag, New York, New York, USA. http://dx.doi. org/10.1007/978-0-387-87458-6 
Appendix 1. Results of mixed-effects regressions of the association between economic and cultural indicators with bushmeat consumption and preference with variable residence length included $(n=227)$.

\begin{tabular}{|c|c|c|c|c|c|c|c|c|c|c|c|c|c|}
\hline \multirow{5}{*}{$\begin{array}{l}{[\mathrm{a}]} \\
{[\mathrm{b}]} \\
{[\mathrm{c}]}\end{array}$} & \multirow{3}{*}{$\begin{array}{l}\text { Economic } \\
\text { Monetary income }\end{array}$} & \multicolumn{4}{|c|}{ Consumption } & \multicolumn{4}{|c|}{ Preference } & \multicolumn{4}{|c|}{ Acceptability } \\
\hline & & \multicolumn{2}{|c|}{$\begin{array}{l}\text { Original } \\
\text { [1] }\end{array}$} & \multicolumn{2}{|c|}{$\begin{array}{c}\text { Standardized } \\
{[2]}\end{array}$} & \multicolumn{2}{|c|}{$\begin{array}{c}\text { Original } \\
{[3]}\end{array}$} & \multicolumn{2}{|c|}{$\begin{array}{c}\text { Standardized } \\
{[4]}\end{array}$} & \multicolumn{2}{|c|}{$\begin{array}{l}\text { Original } \\
\text { [5] }\end{array}$} & \multicolumn{2}{|c|}{$\begin{array}{c}\text { Standardized } \\
{[6]}\end{array}$} \\
\hline & & & $(0.0002)$ & $-0.6279^{*}$ & $(0.3632)$ & -0.0004 & $(0.0004)$ & -0.0798 & $(0.6392)$ & -0.0000 & $(0.0000)$ & -0.0493 & $(0.0309)$ \\
\hline & Wealth & 0.0000 & $(0.0000)$ & 0.0326 & $(0.1876)$ & -0.0000 & $(0.0000)$ & $-0.7016^{\star *}$ & $(0.3336)$ & -0.0000 & $(0.0000)$ & -0.0025 & $(0.0161)$ \\
\hline & $\begin{array}{l}\text { Price perception } \\
\text { Cultural }\end{array}$ & -0.1985 & $(0.1509)$ & -0.4493 & $(0.3048)$ & -0.2576 & $(0.2939)$ & -0.3782 & $(0.6026)$ & $0.0275^{\star}$ & $(0.0151)$ & $0.0515^{*}$ & $(0.0301)$ \\
\hline [e] & Indigenous & -0.3104 & $(0.3974)$ & -0.3237 & $(0.4019)$ & -0.9384 & $(0.7411)$ & -1.0910 & $(0.7759)$ & 0.0205 & $(0.0336)$ & 0.0223 & $(0.0337)$ \\
\hline [f] & Scarcity & $-0.2186^{\star}$ & $(0.1222)$ & $-0.2105^{\star}$ & (0.1222) & -0.1282 & $(0.2177)$ & -0.1710 & $(0.2248)$ & -0.0041 & $(0.0117)$ & -0.0035 & $(0.0116)$ \\
\hline [g] & Illegality & 0.1361 & (0.1203) & 0.3247 & $(0.3021)$ & -0.0177 & $(0.2656)$ & 0.1188 & $(0.5561)$ & -0.0202 & (0.0139) & -0.0429 & $(0.0279)$ \\
\hline [h] & Taboos & -0.1502 & $(0.1215)$ & -0.3372 & $(0.2440)$ & -0.1911 & $(0.2413)$ & -0.4785 & $(0.5057)$ & $-0.0402^{* * *}$ & $(0.0122)$ & $-0.0778^{* * *}$ & $(0.0243)$ \\
\hline [i] & $\begin{array}{l}\text { Social network } \\
\text { Controls }\end{array}$ & $0.4767^{\star * *}$ & $(0.1676)$ & $0.9023^{* * *}$ & $(0.3367)$ & $1.2770^{\star \star *}$ & $(0.3678)$ & $2.7794^{\star * *}$ & $(0.7906)$ & $0.0614^{\star \star *}$ & $(0.0143)$ & $0.1220^{* * *}$ & $(0.0282)$ \\
\hline [j] & Man & -0.0331 & $(0.2108)$ & -0.0464 & $(0.2127)$ & $0.8074^{*}$ & $(0.4274)$ & $1.0018^{* *}$ & $(0.4491)$ & $0.1189^{* * *}$ & $(0.0213$ & $0.1192^{\star * *}$ & $(0.0216)$ \\
\hline$[\mathrm{k}]$ & Age & 0.0100 & $(0.0079)$ & 0.0013 & $(0.0010)$ & $0.0607^{* * *}$ & $(0.0182)$ & $0.0079^{* * *}$ & $(0.0025)$ & $0.0057^{* * *}$ & $(0.0008)$ & $0.0008^{* * *}$ & $(0.0001)$ \\
\hline \multirow[t]{10}{*}[\mathrm{m}]{} & Country & 0.2558 & $\begin{array}{r}(0.4642) \\
-1.2116^{* *}\end{array}$ & 0.0999 & $\begin{array}{r}(0.6006) \\
-1.1794^{* * *}\end{array}$ & -1.0192 & $(0.8291)$ & 0.6153 & (1.0698) & -0.0337 & $(0.0377)$ & -0.0336 & $(0.0490)$ \\
\hline & Constant & & $(0.4872)$ & & $(0.1991)$ & $-2.5362^{* * *}$ & $(0.9300)$ & $-1.5061^{* * *}$ & $(0.3903)$ & $0.2331^{* * *}$ & $(0.0426)$ & $0.4754^{* * *}$ & $(0.0138)$ \\
\hline & Model type & \multicolumn{2}{|c|}{ M.E. Poisson (a) } & \multicolumn{2}{|c|}{ M.E. Poisson (a) } & \multicolumn{2}{|c|}{ M.E. Logit (b) } & \multicolumn{2}{|c|}{ M.E. Logit (b) } & \multicolumn{2}{|c|}{ M. E. Linear (c) } & \multicolumn{2}{|c|}{ M. E. Linear (c) } \\
\hline & Log likelihood & \multicolumn{2}{|c|}{-193.27} & \multicolumn{2}{|c|}{-194.95} & \multicolumn{2}{|c|}{-108.19} & \multicolumn{2}{|c|}{-108.00} & \multicolumn{2}{|c|}{84.91} & \multicolumn{2}{|c|}{85.61} \\
\hline & Prob > chi2 & \multicolumn{2}{|c|}{0.0038} & \multicolumn{2}{|c|}{0.0078} & \multicolumn{2}{|c|}{0.0428} & \multicolumn{2}{|c|}{0.0470} & \multicolumn{2}{|c|}{0.0000} & \multicolumn{2}{|c|}{0.0000} \\
\hline & Random effects & & & & & & & & & & & & \\
\hline & $\sigma u$ (household level) & 0.7630 & $(0.3139)$ & 0.8415 & $(0.3333)$ & 1.8179 & $(1.3140)$ & 2.1897 & $(1.4372)$ & 0.0056 & $(0.0025)$ & 0.0053 & $(0.0025)$ \\
\hline & $\begin{array}{l}\sigma e \text { (individual level) } \\
\text { Intraclass correlation }\end{array}$ & & & & & & & & & 0.0229 & $(0.0028)$ & 0.0229 & $(0.0028)$ \\
\hline & (Rho) & $\mathrm{n}$. & & $\mathrm{n}$. & & 0.3559 & $(0.1656)$ & 0.3996 & $(0.1574)$ & 0.1965 & $(0.0859)$ & 0.1894 & $(0.0856)$ \\
\hline & Observations & 22 & & 22 & & 227 & & 22 & & 22 & & 22 & \\
\hline
\end{tabular}

Notes: (a) Miltilevel Mixed Effects Poisson Regression, (b) Multilevel Mixed Effects Logistic Regression (QR Decomposition), (c) Multilevel mixed-effects linear regression, (d) non applicable.

Standard errors in parentheses

${ }^{*} p<0.10,{ }^{* *} p<0.05,{ }^{* * *} p<0.01$ 